\title{
Falih Rıfkı Atay'ın Ulus Gazetesindeki Yazıları (1935-1937)
}

\author{
Arzu Boya, b, Gökay Durmuşc
}

\section{Özet}

I. Dünya Savaşı'ndan sonraki dönemde Anadolu'da büyük bir mücadele başlamış ve bu mücadele Anadolu topraklarını parçalamaya çalışan dış güçlere karşı yapılmıştır. Anadolu'daki mücadele'nin haklılığını ve Anadolu insanının çektiği sıkıntıların duyurulması amacıyla 14 Eylül 1919'da İrade-i Milliye gazetesi yayınlanmıștır. Gazete aracılığı ile Anadolu'da başlayan hareket herkes tarafından duyulmuştur. Ardından 10 Ocak 1920'de ise Mustafa Kemal'in Hakimiyet-i Milliye olarak belirlediği gazete yayınlanmıştır. Hakimiyet-i Milliye gazetesi 28 Kasım 1934'ten itibaren Ulus adıyla çıkmış ve devletin resmi yayını olarak itibar görmüştür. Ulus gazetesinde Atay, iç ve dış ilişkilerle ilgili birçok yazı kaleme almıştır. Çalışmada; Ulus gazetesinin 19351937 yılları arasındaki bütün sayıları taranmış, Atay'a ait yazılar okunmuş ve değerlendirilmiştir. Çalışma esnasında gazetenin dünyanın ve ülkenin nabzını tutan bir yayın organı olduğu, Atay'ın yazılarının dünyadaki iç ve dış olayları ortaya koyan ve olayları analiz eden yazılar olduğu görülmüştür.
Anahtar Kelimeler

Falih Rıfkı Atay

Diş İlişkiler

Gazete

Ulus

Makale Hakkında

Geliş Tarihi: 21.03.2019

Kabul Tarihi: 24.04.2020

Doi: 10.18026/cbayarsos.542759

\section{Evaluations towards Fatih Rıfkı Altay's Articles in Ulus Newspaper (1935-1937)}

\begin{abstract}
A great struggle started in Anatolia during the period following the World War I and this struggle was made against the external powers who attempted to break up the Anatolian territory. The newspaper İrade-i Milliye was published in 17 September 1919 in order to prove the righteousness of the struggle and to announce the problems suffered by the people of Anatolia. The movement initiated in Anatolia by the means of Newspaper was started to be heard by everyone. Then, the newspaper designated by Mustafa Kemal as Hakimiyet-i Milliye published in 10 January 1920. The newspaper Hakimiyeti Milliye was published with the name "Ulus" since 28 November 1934 and started to be respected with the official publication of Government. In the Ulus Newspaper, Atay has written many articles on domestic and foreign relations. In this study, many issues of the Ulus newspaper between 1935-1937 were scanned, Beloning to Atay's were read and evaluated. During the study, it was seen that the newspaper was a media organ that fingers on the pulse of the world and the country, and that the articles written by Atay revealed the internal and external events in the world and analysed the events.
\end{abstract}

Keywords

Falih Rifkı Atay

Foreign relations

Newpaper

About Article

Received: 21.03.2019

Accepted: 24.04 .2020

Doi: 10.18026/cbayarsos.542759

a İletişim Yazarı: arzunar@hotmail.com

b Dr. Öğr. Üyesi, Kafkas Üniversitesi Sosyal Bilimler ve Türkçe Eğitimi Bölümü, Sosyal Bilgiler Eğitimi ABD, Orcid ID: 0000-00017611-7975.

c Doç. Dr. Kafkas Üniversitesi Sosyal Bilimler ve Türkçe Eğitimi Bölümü, Orcid ID: 0000-0002-8602-1130 


\section{Giriş}

Bilindiği gibi Mustafa Kemal Atatürk'ün lider kimliğinin en önemli unsurlarından biri de ileriyi görme yeteneğidir. Onun Millî Mücadele ve sonrasında cereyan eden sosyal siyasî vak'alar takip edilerek ispatlanabilecek bu özelliği, farklı alanlarda, farklı birçok tutum ve tepkisine de yansımıştır. Atatürk'ün basın yayın faaliyetlerine verdiği önem, bu noktada anılması gereken ilk mevzulardandır. Şöyle ki Mustafa Kemal, daha Harbiye öğrencisi iken basının toplumlar için vazgeçilmez bir kurum olduğunu öngörebilmiştir. Söz konusu dönemde o, memleketteki gidişattan duyduğu rahatsızlığı, çoğunluğu kendisinin yazdığı yazılardan müteşekkil bir gazete aracılığıyla okul arkadaşları ile paylaşmaya çalışmıştır (İnuğur, 1992: 15).

Aynı rahatsızlık, ilerleyen yıllarda Mustafa Kemal'in daha geniş kitlelere ulaşabilme ihtiyacı hissetmesine neden olur ve Fethi Okyar ile bir gazete kurar. Mustafa Kemal bu gazete için maaşlarından artırdığı parayı sermaye olarak kullanır. Gazetenin ismini Minber olarak belirler ve köşesinde yazdığı imzasız yazılarında halkı bilinçlendirme gayesi güder (İnuğur, 1992: 1718). Bu uğraş, Mustafa Kemal'i çok mutlu etse de hedef kitle olan halkın gazetesine duyarsızlığı onu üzer. Falih Rıfkı Atay, Mustafa Kemal'in yaşadığı bu hayal kırıklığı için şunları söyler: "Mustafa Kemal de, gazetesini evinde okur. Pek hoşuna gider, herkesin elinde görmek sevincini tatmak için erken sokă̆a çıkar. Ne kimsenin elinde, ne de satıcıların ağzındadır. Böyle bir gazete çıktı̆̆ından sokaktaki, tramvaydaki ve vapurdaki şehirli habersiz görünür" (Atay, 1968: 182).

Minber, ancak elli sayı yayımlanır ve Mustafa Kemal'in hayatındaki bilinmezlerden birine kapı aralarsa da bu gazete ile yaşadığı hayal kırıklığı onda kalıcı olmaz (İnuğur,1992: 22). Çünkü zaman içinde, özellikle Sivas Kongresi sonrasında, başlayan direniş hareketinin haklılığını ispatlamak, Kuvayı Milliye'nin hedef ve niteliğini, Sivas Kongresi kararlarını dünyaya duyurmak ihtiyacı hasıl olur. Mustafa Kemal, konuyla ilgili olarak "Bir gazete çıkaracă̆ım. Mesul müdürlüğ̈̈nü üzerine olacak itimada şayan biri lazım" (Coşar, 1964: 113) der ve verdiği direktifler ile yeni bir gazete çıkmaya başlar. Yine ismini Mustafa Kemal'in belirlediği İrade-i Milliye'yi, (Coşar, 1964: 113) 14 Eylül-15 Aralık 1919 tarihleri arasında, yani Sivas'tan ayrıldığı sürece kadar Mustafa Kemal yönetir (Tamer, 2004: 39). Gazetenin bu ilk döneminde "ulusal mücadelenin meşrulaştırılması amacıyla tüm yurttan gönderilen telgraflar, saraya ve hükümete gönderilen telgraflar ve imzasız olarak Mustafa Kemal'in yazıları yayınlanır" (Tamer, 2004: 39). Írade$i$ Milliye, kimi zaman ara vermiş olmasına, başlık ve isim değiştirmesine rağmen yayın hayatında kalmayı başarır.

Mustafa Kemal ise bir gazeteye sahip olmak ve gazete aralığı ile iç ve dış düşmanlarla daha sağlıklı savaşabilmek ihtiyacını Ankara'da da duymaya başlar. Sivas'tan Ankara'ya geldikten kısa bir müddet sonra çevresindekilere yine "bir gazete çıkaracağız" direktifini verir. (Coşar, 1964: 122). Çalışmalar başlar ve 10 Ocak 1920'de (Koloğlu, 1993: 26) adını yine Mustafa Kemal' in Hakimiyet-i Milliye olarak belirlediği gazete yayımlanmaya başlar. Mustafa Kemal bir genelge ile Anadolu ve Rumeli'ye gazetenin yayın hayatına atıldığı haberinin ulaşmasını da sağlar (Er, 2006: 56).

Haftada iki gün yayımlanan gazete, daha sonra haftada üç gün, ardından da günlük olarak çıkar. Gazetede bizzat Mustafa Kemal' in dikte ettirdiği, direktifleriyle yönlendirdiği (Er, 2006: 56) yazılar, haberler ve tebliğler, “... ulusal Kurtuluş Savaşı'nın ve Türk bağımsızlı̆̆ının ne kadar akıl almaz güç koşullar altında, Mustafa Kemal'in olağanüstü güç ve yeteneği sayesinde kazanıldığııı kanıtlayan belgelerdir" (İnuğur, 1992: 27). Ayrıca Hakimiyet-i Milliye, Cumhuriyet'e ve devrimlere tanıklık etmiş olmanın getirdiği olanaklar ile yeni rejimi, ilkeleri, devletin 
hedeflerini Türk ve dünya kamuoyuna duyuran uzun soluklu bir yayın organıdır. Öyle ki Mustafa Kemal gazete için "Cumhuriyet'in onuncu yılında Kurtuluş ve inkılabımızın ilk ve sadık işçisi: Hakimiyet-i Milliye" ifadelerini kullanmıştır (Bakacak, 2002: 14).

Özetlenen bu sürecin çalışma açısından taşıdığı önem, Hakimiyet-i Milliye gazetesinin28 Kasım 1934'ten itibaren Ulus adı ile yayımlanmaya başlamasıdır (Bakacak, 2002: 14). Nitekim 10 Ocak 1936 tarihli Ulus gazetesinde ve “Ulus 17 Yaşında" başlığını taşıyan yazıda yer alan bilgiler, bu süreci doğrulamaktadır ve şu şekildedir: "Sivas'taki (İrade-i Milliye'den sonra Hakimiyet-i Milliye) adı ile Ankara'da çıkan gazetemiz bugün on yedi yaşına basıyor. Gazetemizi Atatürk kurmuştur: Ulus, bütün varlı̆̆ı ile onun ve davasının hizmetindedir"(Ulus,10 Ocak 1936, No: 5192, s. 1).

Bu süreçte, 1935'te, ülkede 38 günlük gazete 78 süreli gazete ve 127 dergi yayın yapmaktadır (Gevgilili, 1983; 216). Bütün bu yayın organları içinde en önemlisi ve prestijlisi Ulus'tur. Çünkü Ulus, devraldığı tarihi mirasa uygun biçimde devletin ve elbette ki CHP'nin yayın organıdır. Ulus, bu niteliğinden dolayı devlet kayıtlarına da "Hükümetin resmi bir gazetesidir" şeklindeki ifadelerle geçer (TBMM Gizli Celse Zabıtları, CIII, Ankara, TBMM Basımevi, 1980: 48). Bu nedenle Ulus, CHP'nin Genel Başkanı'na bağlıdır. Genel Başkan ise gazetenin ve matbaanın idaresini CHP Genel Sekreteri'ne bırakmıştır. Gazetedeki önemli konumlara atamalar genel sekreter tarafından yapılmaktadır. Gazetenin, hükümetin dolayısıyla partinin genel politika ve prensiplerine uygun hareket etmesi için bir komisyon kurulmuş ve ayda bir kez fikir alış verişinde bulunulmuştur (BCA, 030.10/79. 522. 3, 1) .

Ulus'un bu nitelikleri gazetenin bir parçası olmayı ve özellikle başyazar olmayı önemli kılar. Falih Rıfkı Atay, Ulus gazetesinde uzun yıllar boyu başmakale yazmış bir isimdir. Fakat Falih Rıfkı ve Ulus birlikte anılırken akla gelen sadece bu değildir. Falih Rıfkı Ulus'taki faaliyetleri ile gazetenin yapılanmasında önemli roller oynar. 30 Temmuz 1931'de başmuharrir olan Atay, daha sonra bu görevi "siyasi murakıplık" kadrosu ile yürütür. Onun bahsi geçen bu faaliyetleri, kendisine "Atatürk'ün dili" denmesine neden olur (Bakacak, 2002: 17).

Ulus gazetesinin bu başyazıları birinci sayfada yer alır ve günün yorumunu içerir. Başmakale yazarı bu yorumlarda, gazetenin gütmüş olduğu politikaya uygun hareket eder (Abadan, 1961: 99). Falih Rıfkı dışında, imzasız yazılar da unutulmamak şartıyla, Mümtaz Faik Fenik, Esat Tekeli, Hüseyin Cahit Yalçın, Yakup Kadri Karaosmanoğlu gibi isimler de başmakalelerinde CHP'nin tutum ve görüşlerini savunurlar (Abadan,1961: 99). Ulus'un kadrosu zengindir. Necip Ali Küçüka, Zeki Mesud, Nasuhi Baydar, Ahmet Şükrü Esmer, Neşet Halil Atay, Burhan Belge, Nurettin Artam, Nurullah Ataç, Yaşar Nabi Nayır, Mecdi Sayman ve Cemal Kutay'ın gazetede yazıları söz konusudur. Gazetenin yazı işlerini de Naşid Hakkı Uluğ, Semih Tiryakioğlu, Münir Berik gibi isimler yürütmüştür (Topuz, 2011: 164).

Ulus'un parti organı olması Ankara kaynaklı siyasi haberlerin gazetede önemli yer işgal etmesinin de kaynağıdır. Yayımlanmaya başladığı günden itibaren, çok partili siyasi süreç dahil, hatta CHP muhalefette iken de siyasi haberler gazete büyük yer tutar.

Ulus gazetesi dış dünyadan haber iletme anlayışını da önemser. Özellikle İkinci Dünya Savaşı sürecinde öne çıan bu tutumun, Türkiye'nin savaş sürecinde oynadığı rolle ilişkisi söz konusudur. Örneğin Kore, NATO vakaları bu durumu tetikleyen kimi vakalardır. Bununla birlikte 1960'lı yıllarda CHP'nin muhalefet partisi niteliğini kazanması gerçeğine bağlı olarak diş haberlerde bir azalma görülür (Abadan, 1961: 96). 
Bilindiği gibi Cumhuriyet sonrasında ülkede yeniden yapılanma süreci başlamıştır. Kültür, sanat, spor, kamuoyunun önem atfettiği kimi sahalardır. Ulus, bu sahaları da yakından takip eder. Örneğin 1939-1946 yılları arasında Ulus'taki spor haberleri gazetenin \%14'ünü kapsayacak kadar yoğundur (Abadan, 1961: 101).

İncelemeye konu olan yıllarda Ulus gazetesin yayın teknik ve politikaları da aynı çizgidedir. Bu yıllar süresince gazete "Adımız, andımızdır" sloganını kullanır ve sekiz sayfa çıkar. Başmakaleler; Betke, Başbetke, Gündellik başlıklarında Falih Rıfkı'ya aittir. Gazetenin bu süreçte "Dış Haberler", "İç Haberler" şeklinde değişmeyen sütunları söz konusudur. Yurttan ve dünyadan verilen bu haberler fotoğraflarla süslenir. Bu sütunlara paralel biçimde, Ulus'ta hem iç basından hem diş basından kimi haber ve gelişmeler de iktibas edilir.

Spor haberlerinin istikrarlı bir düzende yayımlandığı bu yıllarda, Ulus'ta sanat ve kültür haberleri de büyük yer tutar. Özellikle son sayfalarda yoğunlaşan bu haberlerde hemen her gün sinema ve tiyatro ile ilgili gelişmeler ve ilanlar yer alır. Gazetedeki tefrika kitap bölümü ise bazen "Ulus'un Romanı" başlığında bazen kitap isimleri ile verilir. Radyo neşriyatlarından banka ilanlarına, ilaç reklamlarından arsa ilanlarına kadar, ilan ve reklamlar da önemli ölçüdedir.

\section{Falih Rıfkı Atay'ın Gazeteci Kimliği ve Ulus Gazetesi}

Çalışmaya konu olan yıllarda Ulus gazetesinin başyazarı ve imtiyaz sahibi olan Falih Rıfkı Atay'ın çocukluk yılları, Sultan Abdülhamit'in otoriter bir yönetim tarzı güttüğü döneme rastlard. Ailesinin, sultana duyduğu tepki ile şekillenen bu dönem, sonrasında, Atay'1 İttihatçılara yaklaştırır (Şirin, 2014: 9).

İlköğrenimini sıbyan mekteplerinde tamamlayan Atay, daha sonra rüştiyeye devam eder. Rüştiye ondaki tarih ve edebiyat sevgisinin ilk tohumlarının atıldığı yer olur. Osmanlı tarihini ilgiyle takip eden Atay, Namık Kemal'i Tevfik Fikret'i bu yıllarda keşfeder. Servet-i Fünûn, Malumat gibi dergileri takip ederek ülkesini, Fransızca gazeteler okuyarak dünyayı algılamaya çalışır (Çolaker, 2008: 6).

Rüştiye'yi 1905'te bitiren Atay, İstanbul'un en gözde okullarından biri olan Mercan İdadisi'ne başlar. Bu okulun müdürü Hüseyin Cahit Yalçın, Falih Rıfkı'nın edebiyat hocası ise Celal Sahin Erozan'dır (Aktaş, 2013: 15). Erozan, bu dönemde Falih Rıfkı üzerinde etkilidir. Bu nedenle Atay, Muallim Naci ile Recaîzâde Mahmut Ekrem arasındaki tartışmaları, Servet-i Fünûn dergisini, yeni dil ve edebiyat eğilimini takip eder. İdadi, Atay'ın ilk kalem denemelerini de yaptığı yer olur. Erozan'ın yardımı ile ilk şiiri Nisan 1909'da Servet-i Fünûn' da yayımlanır (Çolaker, 2008: 9). Atay, İdadi'nin son sınıfında iken Meşrutiyet ilan edilir ve o bu gelişmeyi heyecan ve coşku ile takip eder (Şirin, 2011: 14).

Atay, Mercan İdadisi'nden 1909'da mezun olur ve Darülfünun'un Ulûm-1 Edebiyye şubesinde yükseköğrenimine başlar. Hırslı ve başarılı bir öğrenci olan Atay'ın edebiyat hocası Mehmet

\footnotetext{
'Falih Rıfkı Atay'ın yaşamı için yararlanılan kaynaklar şöyledir: Funda Selçuk Şirin, İmparatorluk’tan Cumhuriyet'e Bir Aydın: Falih Rıfkı Atay, Birinci Baskı, Tarihçi Kitabevi, İstanbul 2014.

Veysel Çolaker, Türk Siyasal Yaşamında Falih Rıfkı Atay, (Yayımlanmamış Yüksek Lisans Tezi), Anadolu Üniversitesi, Sosyal Bilimler Enstitüsü, Eskişehir 2008.

Şerif Aktaş, “Falih Rıfkı Atay'ın Hayatı ve Sanatı Üzerine Bir Yazı” Falih Rıfkı Atay (Seçmeler) (Hzl. Mustafa Yücel), Berikan Yayınevi, Ankara 2003.

Tanzimat'tan Bugüne Edebiyatçılar Ansiklopedisi, Üçüncü Baskı, Yapı Kredi Yayınları, İstanbul 2010, s. 140-141.
} 
Akif'tir. Bu dönemde Ahmet Haşim, Halit Ziya Uşaklıgil de onun ilgilendiği isimlerdir. Tecelli dergisinde şiirlerini yayımlayan Atay, bu dergide edebî ve siyasi içerikli yazılar da yazar (Çolaker, 2008, 9-10). Bu yazılar, genç bir insanın imparatorluğun nasıl kurtulabileceği yolundaki ilk düşünncelerini içerir. Bu dönemde onun haber kaynaklarından biri de Tanin'deki yazıları ile Hüseyin Cahit Yalçın'dır. Trablusgarp'tan, Afrika'dan, Balkanlar'dan gelen haberler ve yayılan Türkçülük akımı ile Atay, imparatorluk için çıkış yolu olarak Türk kimliğinin benimsenmesi anlayışını gözetmeye başlar (Şirin, 2011: 16). Onun ilk yazısını İttihat ve Terakki Cemiyet'inin yayın organı olan Tanin gazetesine gönderme sebebi bu anlayış olsa gerektir. 30 Ocak 1912' de yayımlanan bu yazıdan sonra (Çolaker, 2008: 10) Falih Rıfkı, Hüseyin Cahit'ten aldığ 1 teklif ile Tanin' in yazar kadrosuna katılır. Önemli İttihatçılar ile tanışma fırsatı yakalamışken Şehbal dergisinde edebî makalelerini yayımlamaktadır. Aynı dönem Atay'ın memuriyet yaşamının da başlangıcını teşkil eder. Önce Sadaret Tahrirat Kalemi'nde daha sonra da Talat Paşa'nın yanında Türkçe katibi olarak Dâhiliye Nezareti'nde çalışmaya başlar (Şirin, 2011: 17). Bu dönemde siyasal düşünceleri açısından Ziya Gökalp'e edebî açıdan Yahya Kemal Beyatlı'ya yakındır (Çolaker, 2008: 13).

Falih Rıfkı Atay, daha sonra 1 Aralık 1926'da Bahriye Nezareti'nde Cemal Paşa'nın Kalem-i Mahsus Müdür Muavini olarak çalışmaya başlar. Cemal Paşa ile birlikte Suriye' de birçok önemli vakaya tanıklık eder. Bu vakalar Atay'da ülkesi ve ülke aydını ile ilgili ironik, sorgulamalara neden olur. Öyle ki Atay Anadolu insanının gücünü ve cesaretini burada keşfeder (Şirin, 2011: 17).

Atay, Suriye'den döndükten sonra 20 Eylül 1918'de arkadaşları ile birlikte Akşam gazetesini çıkarmaya başlar. Burada "Günün Fıkraları" adı altında yazılar yayımlar. Kalemini Türkçülük ve Türkçecilik cereyanları adına kullanır (Aktaş, 2013: 17). Onun İzmir'in işgali üzerine yazdığı yazılarda çıkış noktası, Türklerin var olma savaşı verdiği yönündedir. İstanbul'un işgali üzerine de Millî Mücadele hareketini ve Mustafa Kemal'i destekleyen yazılar kaleme alır. Bu yazılarından dolayı tevkif edilir ve idam cezası ile yargılanırsa da, üç buçuk aylık hapis hayatından sonra serbest kalır (Şirin, 2011: 19).

Falih Rıfkı, 1922'de Anadolu'ya geçer. Millî Mücadele'yi Tanin ve Hâkimiyet-i Milliye'deki yazıları ile desteklemeye devam eder. Yazılarında Türklerin mücadeledeki haklılığını tüm dünyaya duyurmak ve yanlış Türk imajını değiştirmeyi hedefler (Şirin, 2011: 19) Atay'ın Atatürk ile tanışıklığı ise İzmir'in kurtuluşu sonrasındadır. Mustafa Kemal Paşa ile yaptığı uzun röportajdan sonra Mustafa Kemal'in masasında yer bulmaya başlare. Ardından bizzat Mustafa Kemal tarafından Ankara'ya milletvekilliği için çağrılır (Atay, 1968: 22). Bu çağrı onu hem milletvekili hem de Atatürk'ün yakın çalışma arkadaşlarından biri yapar. Öyle ki Atatürk tarafından Hâkimiyet-i Milliye'yi çıkarmakla görevlendirilir (Atay, 1968: 22). Atay artık ulusdevletin inşa sürecinin önemli tanıklarından birisidir. Siyasetten mimariye, Cumhuriyet'in yeni atılımlarının savunucusu olduğu gazetesinde, Atatürk ilke ve inkılaplarının yılmaz savaşçısıdır. Onun 1934'teUlus adını alan gazetedeki faaliyetleri 1947 'de sona erer, fakat gazeteci kimliği devam eder. Cumhuriyet, Yeni İstanbul, Dünya gazetelerindeki faaliyetleri ile yaşamının sonuna kadar Cumhuriyet'e ve Atatürk'e bağlılığını ifade eder. Çok partili yaşam

\footnotetext{
eAslında Falih Rıfkı ile Atatürk'ün tanışma hadisesi daha eskiye dayanır. Yazar, Çankaya'da, söz konusu hadiseyi Mustafa Kemal Atatürk'ün ne kadar kuvvetli bir hafizası olduğu tezini işlerken anlatır. Buna göre 1922'de Falih Rıfkı Mustafa Kemal'e "sizi ilk defa nerede gördüğümü bilir misiniz?" sualini sorar. Mustafa Kemal de evet, dedikten sonra, açıklama yapar. Mustafa Kemal'in 1913'teki bu hadiseyi Falih Rıfkı'ya -üstelik Falih Rıfkı dahi hatırlamıyor iken- anlatması yazarı, hayretler içinde birakir. (Atay, 1968: 561)
} 
sonrasında ise ülkedeki siyasi gelişmeleri muhalif kimliği ile takip eder. Atay'ın uzun soluklu gazeteci kimliği 1959'da aldığ Legiond' Honneur nişanı ile taçlanır (Atay, 1968: 25).

Mutluay'ın "yazı ustalığı" (Mutluay, 1976: 688) sıfatıyla andığı Falih Rıfkı Atay, gezi yazılarından romana edebiyatın farklı türleriyle meşgul olmuş bir isimdir. Onun, Roman(1932) başlıklı ve röportaj biçiminde düzenlediği romanı, halkın Milliyet gazetesine gönderdiği hatıra ve olaylardan esinlenmiştir (Aktaş, 2013: 19). Bununla birlikte Falih Rifkı'da "yaratı türlerine değil, çözümleyici, birleştirici ve değerlendirici biçimlere uygun" bir yazma yeteneği söz konusudur (Mutluay, 1976: 688). Nitekim kendisi de gazetecilik yönü için "kendi mesleğim" ifadesini kullanır (Atay, 2003: 28). Bu yetenek Falih Rufkı'nın “gazete"yi pragmatist bir yaklaşımla değerlendirmesine ve "gazete" ye önemli sorumluluklar yüklemesine neden olmuş gibidir. Bu noktada Falih Rıfkı'nın genç yaşlarından itibaren, kitle iletişim araçlarının toplumsal yaşamlar açısından ne derece önemli olduğunu gözlemleyebildiği söylenebilir. Bilindiği gibi basın, haber iletme, kamuoyunu bilgilendirme, sosyal yaşama katkı olma gibi görevleri olan bir kurumdur. Modern yaşam bu görevlere, ideolojik ve sistemsel yeni görevler eklemiştir. Basın artık, toplumsal sistemlerin ve devletin "ideolojik aygıtlarından" birisidir. Falih Rıfkı'nın gazeteye yönelik pragmatik yaklaşımında çıkış noktası -geleneksel görevlere duyduğu bağlılığı da göz ardı etmemek şartı ile- gazeteyi "ideolojik bir aygit" olarak görmesidir (Althusser, 1989: 29 ). İmparatorluktan ulus devlete uzayan çizgide, kimliğimizin bileşenlerini belirleyebilmek, Türk toplumunun modernleşme çabasına katkıda bulunmak ve hedefler üretmek ve elbette Mustafa Kemal ve Millî Mücadele'nin anlam ve önem kazanmasını sağlamak uğrunda kullandığı kalemi, onu Türk kamuoyunda "belirleyici" tutum ve tepkilerin sahibi yapmıştır (Şirin, 2011: 4). Bu anlamda Falih Rıfkı'nın gazeteyi "bir terbiye müessesi" (Atay, 2003: 28) olarak görmesi önemlidir. Falih Rıfkı'nın bu anlayışa binaen gazetelerimizin daha kaliteli yayın yapması gerektiği yolundaki tezleri ise bugün dahi geçerliliğini koruyacak cinstendir. Buna göre gazetelerimiz satış ihtiyacı hissettikleri için kullandıkları sokak üslubunu, boy boy resim ve fotoğraf basma anlayışını bırakmalı, hacim küçültmeli ve seviyelerini yükseltmelidirler. Bu sağlanırsa gazete okurunun da seviyesinin artacağı kesindir (Atay, 2003: 29).

\section{Falih Rıfkı Atay'ın Dış Dünya'ya ve Türk Dış Politikasına Yönelik İlgisi}

\section{Habeşistan Meselesi}

Falih Rıfkı Atay'ın söz konusu süreçte Ulus gazetesinde yer alan ve dış dünyaya yönelik ilgisini örnekleyen yazıları, iki temel tez ekseninde gelişir. Bunlardan ilki Avrupa devletlerinin emperyalist politikalar geliştirdiğine (yürüttüğüne) yönelik tezdir. Yazar bu düşüncesine dayanak olarak 18 Haziran 1935 tarihli Avrupa İşleri başlığını taşıyan yazısında Uluslar Sosyetesi'nin Milletler Cemiyeti) işlevini mercek altına alır. Bunu "zamanımızın en büyük davalarından biri" olarak lanse eder ve Avrupalıların da aynı meseleyi tartıştığını belirterek yazısına başlayan Atay, İngiliz ve İtalyan gazetelerinden iktibaslar da yapar. Buna göre Avrupa gazeteleri Uluslar Sosyetesi'nin güçlü ülkelerin çıkarlarını koruyan tutumunu eleştirmektedir. Falih Rıfkı ise Uluslar Sosyetesi'nin kurulduğu zamandaki coğrafi şartları ve antlaşmaları kabul ettiğini, bu nedenle toprak paylaşımı konusunda taraf olmaması gerektiğini düşünür. Yazara göre bu kuruluşun dünyadaki coğrafi sınırları değiştirme, sömürge belirleme, dünya statükosunu yenileme işlevi yoktur. Yazar 13 Mayıs 1936 tarihli 
yazısında da Milletler Cemiyeti'nin dünya barışını ve bütün ülkelerin emniyetini sağlamak yolunda bir görevi olduğu tezini işlerf.

Falih Rıfkı Atay Habeşistan meselesinin İtalyanlar açısından da olumsuz birtakım sonuçlara neden olduğunu düşünür. Örneğin 9 Aralık 1935 tarihli yazısı bu düşüncesini içerir. Yazar Sömürge Ticareti başlıklı yazısında $\mathrm{Vu}$ gazetesinin bir haberinden yola çıkar. Gazete, Avrupa'nın emperyalist devletlerinin sömürge ülkelerde harcadığı para, teçhizat ve gönderdiği asker sayısı ile ilgili olarak bilgi paylaşmıştır. Falih Rıfkı İtalya'nın Habeşistan seferinin de hem maddi hem manevi açıdan İtalyan Devletine büyük yükler getireceğine inanmaktadır. Falih Rıfkı'nın uyarı mahiyetinde kabul edilebilecek bu öngörüsü elbette ki İtalyan hükümetinin Habeşistan'1 işgaline engel olmamıştır. Yazar bu gerçekten hareketle Habeşistan meselesini neredeyse adım adım izler. Dış dünyadan aldığı bilgi ve haberleri yorumlar. Örneğin 5 İlkteşrin 1935 tarihli başyazısında Afrika harbinin başladığını belirtir. Yazara göre artık, "Harb olur mu olmaz mı", "Eğer harb olursa" gibi yorumların hükmü kalmamıştır. Nitekim yazar 22 İlkteşrin 1935 tarihli başyazısında da İtalyanların Doğu Afrika'ya her gün yeniden asker yolladıkları bilgisini paylaşmıştır. 2 Mayıs 1936 tarihli başbetkede de resmî İtalyan tebliğlerini değerlendirir. Buna göre İtalyan kuvvetleri Adisababa'nın yüz kilometre yakınına kadar ilerlemişlerdir. Yazarın verdiği tarihi bilgiler olayların oluş tarihi ile uyuşmaktadır. Habeşistan aynı tarihte İtalyanlar tarafından ele geçirilmiştir. Öte taraftan 9 Mayısta ise Habeşistan'ın İtalya'ya ilhakı duyurulmuş ve İtalya kralı aynı zamanda Habeşistan imparatoru ilan edilmiştir (Armaoğlu, 1991: 137).

Falih Rıfkı Atay İtalyanların Afrika topraklarındaki bu hızlı ilerleyişini Afrika ülkelerinin dolayısıyla Habeşistan'ın da teçhizat bakımından zayıf olduğu gerçeğine bağlayarak tahlil eder. Yazar bu tezini hem 2 Mayıs 1936 tarihli yukarıda bahsi geçen yazısında hem de 8 Aralık 1935 tarihli yazısında işler. Yazar 8 Aralık 1935 tarihli yazısında Habeşistan'ın teknoloji yoksunluğunu resmettikten ve bunun Habeş ordusunun zayıflığının temel nedeni olduğunu belirttikten sonra durumdan pay çıkarır. Buna göre Türkiye dahil tüm ülkelerin; hava, deniz, demir yollarını sağlam kurmuş olmaları, sağlam ve güvenilir savunma sistemleri geliştirmiş olması şarttır. Diğer taraftan Habeşliler ilkel silahlarla mücadele etmiş olmalarına rağmen kolay pes etmemişlerdir (Armaoğlu, 1991: 137).

\section{Boğazlar Meselesi ve Montrö Boğazlar Sözleşmesi}

1929'da tüm dünyayı etkisi altına alan ekonomik buhran, Avrupa ülkelerinin de güç kaybetmesine neden olur. Nitekim Falih Rıfkı Atay da bu süreçte Avrupa ülkelerini "hasta adam" sıfatıyla niteler (Ulus, 24 Nisan 1935, No: 4934, s. 1, 2). Bu güç kaybı Avrupa ülkelerinin yeni kaynak arayışını ve silahlanma yarışını hızlandırır. 1933'te Japonya Milletler Cemiyeti'nden ayrılır, Almanya ise Cenevre Silahsızlanma Konferansı'ndan çekilir. İtalya, Habeşistan'ı işgal ve Londra Konferansı ise başarısızlıkla sonuçlanır. Bütün bu gelişmeler Lozan sonrasında iç meselelere yoğunlaşan Türkiye'yi endişelendirmeye başlar. Çünkü Milletler Cemiyeti, İtalya'ya bir yaptırım uygulamaz ve Türkiye'nin Cemiyet'e güveni sarsılır.

\footnotetext{
f Milletler Cemiyetinin en önemli amaçlarından biri barışı korumak ve devletlerarasında çıkabilecek anlaşmazlık ve çatışmaları barışçıl çözümlere kavuşturarak olası savaşları engellemek idi. Uluslararası ilişkilere yeni bir düzen getirme anlamında önemli bir sorumluluğu üstlenmiş Cemiyet, milletlerarası işbirliğini geliştirmek ve milletlerarası barıș ve güvenliği koruma amacını benimsemişti (Kıran, 2008: 19-36).
} 
Lozan Antlaşmasında Boğazların güvenliği konusunda varılan kararların milli menfaatleri korumaya yetmeyeceğine dair bir görüş birliğine varılması ise Türkiye'nin 11 Nisan 1936'da Lozan Boğazlar sözleşmesine imza atan ülkelere bir nota vermesi ile sonuçlanır. Nota, İtalya dışındaki ülkeler tarafından olumlu karşılanır ve 22 Haziran 1936'da Montrö Boğazlar Konferansı toplanır (Uçarol, 2010: 761).

Ulus gazetesi bu süreci yakından takip eder ve gelişmeler konusunda Türk kamuoyunun önemli haber kaynaklarından biri olur. Gazetenin bu meseleye verdiği öneme binaen, Falih Rıfkı da süreci izler ve yorumlar. Yazar 3 Teşrinisani 1935 tarihli “Bizim Davalarımız” başlıklı yazısında Türk Dış Politikasının iki önemli ayağını şu sözlerle ifade eder: "Yurdumuzu ve halkımızı müdafaa edecek kuvvette olmak, sulhu koruyacak arsıulusal çalışma birliğine önem vermek..." Dolayısıyla Falih Rıfkı Atay'ın, Türkiye'nin barış ve huzur içinde yaşaması adına, uluslararası kamuoyundan hassasiyet beklediği ortadadır. Söz konusu hassasiyet, 1936 Haziran'ında başlayacak olan görüşmeler için de öngörü niteliğindedir. Falih Rıfkı'nın dünyaya yönelttiği ve beklentilerini dillendirdiği bu sesinde, bir hareket noktası söz konusudur. Bu, aynı zamanda Falih Rıfkı Atay'ın dış dünyaya yönelik ilgisinin ikinci temel tezidir. Şöyle ki Falih Rıfkı Atay, yazılarında sık sık Türkiye'nin barışçıl bir dış politika güttüğü konusunda cümleler kurar. Fakat bu barışçıl politika, emniyet ve hürriyet davalarımızdan vazgeçeceğimiz anlamına gelmemektedir. Yazarın bahsi geçen nota sonrasında 21 Nisan 1936 tarihli ve “Notamız Etrafında” başlıklı yazısı, konuyla ilgili düşüncelerinin özetidir:

“Barışçı olduğumuz kadar, Türkiye'nin emniyet ve hürriyet davasına bağlıyız. İki tarafl, birkaç taraflı veya her taraflı bütün anlaşmalarda dünya barışının ve Türkiye güvenliğinin gerçek dayançları olup olmadığını ararız. Taarruz etmek ne kadar fikrimizden uzaksa, taarruza uğraşmak tehlikesini o kadar imkânsızlaştırmak isteriz."

Görüldüğü gibi yukarıdaki sözler, notanın meşruiyetini ortaya koyma çabasının ürünüdür. Yazısının devamında da Atay aynı fikri savunur. Buna göre Türkiye Lozan'da birtakım kararlara imza atmış ve bu kararlara sonuna kadar bağlı kalma sözü vermiştir. Fakat bu, Türkiye'nin emperyalist faaliyetlere göz yumacağı anlamına gelmemektedir. Ayrıca Türkiye' nin ve Doğu coğrafyasının güvenliği konusunda önemli bir konumu olan Boğazlar'ın işlevi, Türkiye'nin sorumluluğundaki bir konudur. Hatta söz konusu güvenlik, Türkiye'nin dostu olduğunu savunan her ülke için önemlidir. Dolayısıyla Boğazlar meselesi, Avrupa'nın gündemindeki diğer meselelerle eş tutulamayacak bir meseledir. Atay bu düşünceden hareketle 1936 Haziran ve Temmuz aylarındaki yazılarında sıkça İtalya, Rusya ve İngiltere'yi eleştirir. Örneğin 26 Haziran 1936 tarihli yazısı_ “Konferans ve İtalya” başlığını taşır. Yazının girişinde Rusya hükûmetinden Ankara hükûmetine gönderilen bir mektup söz konusudur.

Mektup İtalyanların Montrö’ye temsilci göndermediği bilgisini içermektedir ki İtalya Montrö'ye hakikaten temsilci göndermemiştir (Yel, 2009:107). Ayrıca İtalyan gazeteleri de Türkiye'nin verdiği notanın haksız olduğunu ve Roma Hükûmeti'nin Montrö'de alınacak kararları tanımayacağını yazmıştır. Bu gelişmeler, Falih Rıfkı'nın yeniden Türkiye'nin Boğazlar konusundaki hassasiyetini ve haklılığını işlemesine neden olur. Yazar makalesinin devamında, İtalyan kamuoyunun bir yanılgı içinde olduğunu ve İtalyanların bu mevzuyu tartışmasının anlamsızlı̆̆ını vurgular. Nitekim Atay, 10 Teşrinievvel 1936 tarihli yazısında da Türkiye'nin “... on sekizinci asırdan beri devam eden eski Boğazlar Meselesi'ni tekrar diriltmek niyetinde olmadığını ve revizyoncu bir politika izlemediğini” belirtir.

Atay14 Temmuz 1963 tarihli yazısına, Rusya'nın tüm dünyada bilinen sıcak denizlere inme politikasını özetleyerek başlar. Ardından Rusya'nın Montrö'de ileri sürdüğü savları eleştirir. 
Yazar, Rusya'nın yeni Türkiye'nin maddi ve manevi gücünü göz ardı ettiğini ve Türkiye'yi hâlâ 18. yüzyılı yaşayan bir devlet olarak gördüğünü belirtir. Halbuki Türkiye Boğazlar konusunda taraf olması gereken en önemli ülkedir ve her alanda gelişmekte ve yenilenmektedir. Atay bu yazısında İngiltere'nin de Boğazlar konusundaki politikasını eleştirir. Ona göre "Akdeniz'in dış kapısından birine sulh kilidi takılması" İngiltere'nin de yararınadır. Yazar5 Temmuz 1936' daki yazısında da Rus gazetelerinin Montrö' deki gelişmeler konusunda yaptığı yorumlardan alıntılar yapar.

Falih Rıfkı Atay, Montrö müzakerelerinin Türkiye lehine sonuçlanmasından büyük memnuniyet duyar. 18 Temmuz 1936 tarihli yazısında süreci özetler ve hem Türkiye hem müzakerelere taraf olan ülkeler açısından hakkaniyetli bir tutum takınmaya çalışır. Ona göre Boğazların güvenliğinin ve geleceğinin garanti altına alınması elbette ki çok önemlidir. Fakat sürecin bir başka önemli boyutu da Türkiye'nin Avrupa devletleri ile eş seviyede görüldüğünün kabul edilmiş olmasıdır. Atay, bu başarıdan oldukça memnundur ve bunu İnkılap rejiminin başarısı olarak görür: “Lozan'daki itibarımız zaferin, Montrö'deki itibarımız inkılap rejiminin eseridir" şeklinde düşüncelerini ifade eder.

\section{Falih Rıfkı Atay'ın Hatay Meselesi ile ilgili Yazılan}

Türkiye ile Fransa'nın 20 Ekim 1921'de imzaladığı Ankara Anlaşması sonucunda Suriye Fransa'nın manda yönetimi uyguladığı bir bölge haline gelmiştir (Yalçın ve Diğerleri, 2000: 249). Ancak Fransa, 1936 yılında Suriye mandaterliğinden ayrılacağını açılayınca Hatay, Türkiye dış politikasının önemli bir meselesi haline gelir. Ulus gazetesi, Türk dış politikasını yakından takip eden ve Türk kamuoyunu çeşitli meseleler hakkında bilgilendiren en önemli yayın organlarından biri olduğu için, Hatay meselesine de ilgiyle yaklaşır. Gazetenin bu politikası Falih Rıfkı'nın da yazılarına yansır ve Falih Rıfkı meseleyle ilgili günlük gelişmeleri yorumlayan isim olur.

Daha önce belirttiğimiz gibi, Falih Rıfkı'nın dış dünya ve dış dünya-Türkiye konulu meselelere bakışında ikinci temel tezi, Türkiye'nin barışçl bir dış politika izleme çabasında olduğu yönündedir. Nitekim yazarın Hatay meselesine bakışı da bu tez ekseninde gelişir. Yazar 25 Eylül 1936 tarihli yazısında, Fransa'nın yukarıda bahsi geçen mandaterlikten çekilme kararını sevindirici bir gelişme olarak görür. Çünkü Atay bu gelişmeyi Suriye'nin "hür ve müstakil" yaşama hakkının kabulü olarak algılar. Yazarın bu kabulünde çıkış noktası sadece Suriye değildir. Atay, Türkiye'nin, tüm Arap devletlerinin hür bir biçimde ve huzur içinde yaşamalarını istediğini belirtir. Ona göre Arap devletlerinin sulh ve saadet içinde yaşaması, emperyalizmin çökmesi, dünya barışının galip gelmesi demektir. Ayrıca Türkiye, Arap devletleri ile ortak bir kültüre, ortak bir tarihe sahiptir. Bu nedenle Suriye'nin manda yönetiminden kurtulması, elbette ki Türkleri memnun eden bir gelişmedir. Atay 12 Şubat 1937 tarihli yazısında da benzer düşünceleri işler ve Türkiye'nin Asya'daki barışı desteklediğini ifade eder.

Falih Rıfkı Atay'ın, Hatay meselesindeki bir diğer hareket noktası ise Türkiye'nin Hatay konusuna bakışındaki haklılığını ispatlama çabasıdır. Bu çaba Türkiye Cumhuriyeti Devlet'inin ve Ulus gazetesinin konuyla ilgili görüşlerine paralel bir çabadır. Falih Rıfkı, Hatay sancağında yaklaşık 250.000 Türk'ün yaşadığını ve Suriyeliler gibi Türklerin de özgür yaşam hakkına sahip olduklarını düşünür. Bu düşüncesini 25 Eylül 1936 ve 30 Eylül 1936 tarihli yazılarında işleyen Falih Rıfkı, Hatay'daki kimi vakaları işaret ederek konuşur. Örneğin 30 
Eylül 1936'daki yazısında bir Türk bayrağının parçalandığı ve Şam gazetelerinin Türkiye'ye karşı düşmanca haberler yaptığını ifade eder. 13 Ocak 1937 tarihli Ulus gazetesinde, "Sancakta Kanlı Bir Çarpışma" başlığıyla Hatay'da Türk vatandaşlara saldırılar düzenlendiği ve dört Türk vatandaşın öldürüldüğü bildirilmektedir. Falih Rıfkı bu haberi köşesine taşırken Hatay Türklerinin zor şartlarda yaşadığını belirtir. Aynı yazıda Atay, 21 Ocak tarihinde Milletler Cemiyeti'nin Hatay meselesini görüşmek üzere toplanacağı bilgisini de verir. Yazarın bu görüşmeyle ilgili iki ön görüsü söz konusudur. Bunlardan ilki, Hatay meselesinin sürüncemede bırakılacak bir mesele olmadığı yönündedir. Yazarın ikinci ön görüsü ise Hatay Türklerinin hak ve hürriyetlerinin emniyet altına alınması gerektiğine dairdir.

Atay'ın 1937 Ocak yazıları, bahsi geçen toplantı ile ilgili olup Fransızların takındığı tutumu eleştiren saptırmalar barındırır. Örneğin yazar, 20 Ocak tarihli yazısında Fransız memurların Hatay'daki Türk nüfus hakkında dünyaya verdiği bilgilerin yanlış olduğunu işler. Bu arada 21 Ocak'ta Miletler Cemiyeti toplanırsa da Falih Rıfkı 21 Ocak tarihli yazısında Fransa'nın uyguladığı diplomasinin ve Hatay konulu tekliflerinin, Hatay'da barış ve huzuru sağlamaktan uzak olduğunu belirtir. Yazar 22 Ocak tarihinde Fransızların Milletler Cemiyeti'ni etkilemeye çalıştığını ifade ederken 23 Ocak tarihinde Fransız gazetelerinin Türkiye, Hatay ve Milletler Cemiyeti ile ilgili yaptığı haberleri yanlı ve yanlış bulur.

Süreç içinde Türkiye'nin kararlı tavrı, Fransızların daha olumlu tavırlar takınmasına neden olur. Ulus gazetesinin 25 Ocak tarihli nüshasında Cenevre' de yapılan görüşmelerin sonucunda bazı esaslar üzerinde karar kılındığı bilgisi vardır. Gazete bu kararları büyük puntolarla verir. Falih Rıfkı ise kararların altında, fakat bu defa köşe yazısı niteliği taşımayan bir yazı kaleme alır. Atay bu yazısında varılan kararlara sevindiğini, fakat bunların kağıt üzerinde kalmaması gerektiğini belirtir. Ona göre bu kararlar ancak uygulanırsa bölge barışına hizmet edebilecektir. Yazara göre kararlar Türkiye Cumhuriyeti Devleti'ni rahatlatmışsa da meselenin bütün boyutlarıyla halledildiği anlamına gelmemektedir.g

Ulus gazetesinin 29 Ocak 1937 tarihli nüshasında, Hatay meselesi ile ilgili son gelişmeler üzerinde durulmaktadır. Buna göre Atatürk Cenevre'deki Türk heyetine teşekkür etmiştir. Ayrıca gazete, $\mathrm{CHP}^{\prime}$ ye meselenin halledilmesi ile ilgili olarak gönderilen kimi tebrik telgraflarını da yayımlar. Falih Rıfkı ise söz konusu tarihteki yazısında Atatürk'ün mesajını yorumlar ve Hatay ile ilgili son gelişmeyi Türk Cumhuriyeti Devleti'nin yeni bir zaferi olarak görür.

29 Mayıs 1937'de sancağın millî bütünlügünü teminat altına alan ve yeni Türkiye- Suriye sınırını tespit eden bir anlaşma yapılmıştı. Ardından 29 Mayıs 1937'de Hatay için ayrı bir anayasa kabul edilmiş ve aynı tarihte imzalanan bir antlaşma ile İskenderun toprak bütünlüğü garanti altına alınmıştı. 2 Eylül 1938' de kurulan Hatay devleti bir yıl bağımsız kaldıktan sonra 23 Haziran 1939'da Türkiye'ye katılmıştır (Dayı, 2002: 331-240).

\section{Falih Rıfkı Atay'ın Farklı Ülkeler ile İlgili Düşünce ve Gözlemleri}

Falih Rıfkı Atay, hem Ulus gibi önemli bir yayın organının başyazarı olmanın getirdiği sorumlulukla hem gözlemci kişiliğinin katkısıyla dış dünyayı takip etmeyi asla bırakmaz. Bu takip, onun başyazılarında işlediği tüm konularda olduğu gibi, gazetenin önem göstererek işlediği diğer mevzularla da yansımasını bulur. Örneğin çalışmaya esas teşkil eden yıllarda

gNitekim Atay'ın 13 Mart 1937 tarihli yazısında, Suriye'nin Hatay konusunu bir tahrik malzemesi yaptığı şeklinde yorumlar söz konusudur. Gazetede ise Hatay'da Türk köylerinin basıldığı yolunda haberler vardır. 
Balkan Antantı önemli bir gelişmedirh ${ }^{\text {h }}$ Ulus gazetesi, bu gelişmeyi adım adım izlerken halkın haber alma ihtiyacı kapsamında yorumsuz bilgi ve fotoğraflar yayımlar. Belli ki konuyla ilgili yorum yapma görevi, Falih Rıfkı'nındır. Falih Rıfkı bu gelişmeyi "Balkanlı" ruhu adını verdiği bir kavram ekseninde yorumlar. 27 Haziran 1936' daki "Balkanlı" başlığını taşıyan yazısında, Balkan ülkeleri arasında birlik ve beraberlik arzuladı̆̆ını ifade eder: “...Balkanlılar olarak o kadar mücadele karşıll̆ğı elde ettiğimiz hürriyet ve şahsiyetlerimizi birlikte müdafaa edeceğiz. "Yazar bu ruh gereği Balkan ülkelerinin "Türk düşmanlığı" yapmaktan vazgeçmeleri gerektiğini düşünmektedir. Bu nedenle de 18 Şubat 1937'deki Atina'da başlıklı yazısında Balkan Antantı'nı "şuurlu ve karşılıklı tam bir menfaat ve mesuliyet anlayışının" eseri olarak görür. Aynı düşüncesini 6 Ocak 1937'de yayımlanan yazısında da işler. Buna göre Balkan Antantı, "Balkanlar emniyet ve barışın, bütün Balkan devletlerinin el ve ülkü birliği ile temin etmek" amaciyla imzalanmıştır.

Yukarıda bahsi geçen "Balkanlı" ruhu, Falih Rıfkı Atay'ın başyazılarında sık sık Balkan ülkelerini konu edinmesinin de nedeni olsa gerektir. Örneğin yazar 1936 yılı Eylül ayındaki yazılarında Yugoslavya'da başlığı altında Yugoslavya'ya yaptığı geziyi konu edinir. Atay sohbet üslûbuyla kaleme aldığı bu yazılarında, Yugoslavya coğrafyası, kültürü, tarihsel dokusu, gündelik yaşamından gözlemlediği durum ve vakaları okuruyla paylaşır. Onun 3 Mayıs ve 17 Mayıs 1935 tarihli yazıları ise yine Yugoslavya ile ilgili olup, yazarın yaptığı yorumlar ve paylaştığı düşünceleri bu kez siyasîdiri.

Atay bahsi geçen sohbet edasını 27, 29 Haziran ve 1 Temmuz 1936 tarihli yazılarında bu defa da Romanya için sürdürür. "Romanya Mektupları" başlığını taşıyan bu yazı dizisinde de Atay, Bükreş merkez olmak üzere Romanya coğrafyası, kültür, insanı ile ilgili tespitleri işler.

Bilindiği gibi II. Dünya Savaşı öncesinde Avrupa'da cereyan eden en önemli hadiselerden birisi de İspanya iç savaşıdır. Ulus gazetesi bu hadiseyi yakından takip eder. Gazetede hem İspanyol basınından hem farklı ülkelerin basın yayın organlarının sık sık iktibas edilen haberlerle İspanya'da neler olup bittiğini izlenir. Falih Rıfkı, bu haberleri ve İspanya'daki siyasi gelişmeleri sütununda yorumlar. Yazar 11 Ağustos 1936' daki yazısına "İspanya faciası" başlığını koyar ve bu iç savaşın mahiyetini yorumlar. Ona göre İspanya'da halk ile faşistler arasında yaşanan savaş, ülkenin potansiyelinin boşa harcanmasına neden olmaktadır. Yazar 28 Şubat 1937 tarihli yazısında ise özellikle Avrupa ülkelerinin İspanya'daki tutumları, hangi kesimi niçin desteklediklerine dair düşüncelerini paylaşıri.

Atay'ın Avrupa ülkelerine yönelik ilgisi, İspanya meselesi dışında farklı meseleleri de kapsar. Örneğin Falih Rıfkı, Avrupa ülkelerinde yapılan seçimleri sık sık köşesinde işler. Yazar; 17 Haziran 1935 tarihli yazısında Yunanistan'da, 17 Kasım 1935 tarihli yazısında İngiltere, 31 Mart 1936 tarihli yazısında Almanya' da gerçekleşen seçimleri yorumlarken seçim neticelerinin hem seçim yapılan ülke hem dünya için ne tür gelişmelere yol açabileceğini tartışır.

\footnotetext{
h 1934 yllında Türkiye, Yunanistan, Yugoslavya ve Romanya arasında Balkan Antantı imzalanmıștır. Antantın hükümlerine göre dört devlet birbirlerinin Balkan sınırları konusunda güvence vermişler ve çıkarlarına yönelen bir tehdit durumunda birbirleriyle görüşmelerde bulunmayı taahhüt etmişlerdir ( Sander, 2011: 103).

i Atay’a göre, Yugoslavya o yıllarda "vahdet buhranı" içindedir. Buhranın sebebini Hıristiyanlıktan kaynaklanan kültür ve din ayrılığına bağlar. Yugoslavya geçmişten beri farklı etnik grupları ve dinleri bünyesinde taşır. Falih Rıfkı Atay, Yugoslavya'nın etnik bakımdan birlik içinde olması gerektiğini dile getirmiştir. Yugoslavya'da bir rejim değişikliğinin olduğunu ve Yazar, Türklerin, Yugoslavya'nın "istikrar mücadelesini” takip ettiğini "yeni rejimin başarılarını da sevinçle karșıladığını" söylemiş ve Yugoslavya'nın gelişiminin bizim içinde mutluluk olduğunu izah etmiştir (Girgin, 2012: 86). j Atay, İspanya'yı Avrupa'da olmasına rağmen gelişmemiş bir yer olarak değerlendirmiş ve beğenmemiştir. ( Girgin, 2012: 86).
} 
Bu açıklamalar, Falih Rıfkı'nın dış dünyaya yönelik ilgisinin, Avrupa ile sınırlı olduğu şeklinde bir yanlış düşünce doğurmamalıdır. Onun yazılarında, Doğu dünyasına ait haberler de büyük orandadır. Bu noktada ilginç olan Falih Rıfkı'nın Doğu dünyasına yönelttiği projeksiyonunda hareket noktasının Şark-Garp karşılaştırması olmasıdır. Öncelikle yazar Türkiye' nin dış dünyadaki imajından rahatsızlık duymaktadır. Bu düşüncesini 5 Ağustos 1935 tarih ve "Türkiye Bu Değildir" başlıklı yazısında dile getiren Atay, Brüksel'deki bir sergiyi konu edinmektedir. Türkiye'nin bu sergiye sadece tütün çeşitleriyle katılması Atay'ı rahatsız etmiştir. Ona göre Türkiye dünyaya gerektiği gibi tanıtılmamaktadır. Türkiye' de sadece tütün yetişmediğine göre, yetkililerin konuyla ilgilenmesi gereklidir. Yazar 17 Ocak 1936 tarihli yazısında ise İran'ı merkeze alarak Şark memleketlerinde din kisvesi altında gerçekleştirilen gerici faaliyetleri tartışır. Yazara göre Şark'ın Garp medeniyetine sömürge ve esir olmaması için gaflet uykusundan uyanması gerekir. Atay bu fikrini İran Şahı Rıza Pehlevî'nin konuyla ilgili özet olarak algılanabilecek nutkundan küçük bir alıntı ile bitirir. Yazar, Şah Pehlevi'yi 15 Mart 1936 ve 15 Mart 1937 tarihli yazılarında da anar. Her iki yazısında da İran'ın Rıza Pehlevî ile büyük bir atılım başlattığı yolunda yorumlar söz konusudur. Yazara göre Şark, mazinin parlak ve mesut günlerini, ancak şimdiki medeniyet âleminde bir yer edinerek yaşayabilir ve bu nedenle İran'daki atılımlar önemlidir. Atay'ın 6 Ocak 1936 tarihli başyazısında ise Afganistan Dış İşleri Bakanı Feyz Mohammed Han'ın Ankara ziyareti hakkında bilgi ve yorumlar söz konusudur. Yazar Afganistan'ın barış içinde yaşamasını önemser ve Türkler gibi Afgan halkının da çok çalışması gerektiğini düşünür.

\section{Falih Rıfkı Atay'ın Atatürk ve İlkeleri Konulu Yazıları}

Anı, deneme türü yazılarının sayıca kabarık olduğu bilinen Falih Rıfkı'nın hemen her eserinde dikkat çeken bir arka plan rengi söz konusudur (Atay, 2003: 593): Atatürk sevgisi ve bağl1lı̆̆1. Konuyla ilgili akla gelen en bilindik eseri Çankaya'da, Atatürk'ün "asrının en büyük adamı" olduğunu belirten Falih Rıfkı'nın bu düşüncesi Ulus gazetesindeki yazılarına da yansımıştır. Atay, "Kemalizm" kavramı ile ifade etmeyi tercih ettiği söz konusu sevgi ve bağlılık için 19 Mayıs 1935 tarihli "Davamız" başlıklı yazısında şu cümleleri kurar: "Kemalizm, her şeyin üstünde, bir kültür ve medeniyet savaşıdır." İşte Atay, Atatürk konulu yazılarında bu savaşın geçtiği süreci, karşılaştı̆̆ zorlukları, halktan gördüğü desteği yahut muhalif kimi görüşleri ve elbette Kemalizm'in esaslarını tahlile çalışır. Örneğin yukarıda bahsi geçen yazısında Kemalizm'in en temel esasının "vicdan özgürlüğü" olduğunu ifade eder. Atay'a göre Kemalizm'in eseri olan bu özgürlük, şimdiye kadar bütün Doğu medeniyetlerinin uzak kaldığı bir kavramdır. Bu kavramın yönetim şekli olan Cumhuriyet ise yalnız bir rejim adı değildir; Cumhuriyet "bir kültür ve medeniyet ismidir." Atay, 21 Şubat 1936 tarihli yazısında da Kemalizm'i “bir kurtuluşun değil, bütün kurtuluşların sentezi” olarak kabul eder ve Türkiye Cumhuriyeti Devleti'nin Kemalist ilkelerden ayrılmaz ise tarihe kaydedilecek bir devlet olacağını vurgular. Aslında Atay'ın 21 Şubat 1936 tarihli bu yazısı Medeni Kanunu'nun kabulünün yıldönümüne ayrılmış bir yazıdırk. Atay, bu yazısında önce, Tanzimat'ın ilanı ile hız kazanan Batılılaşma tarihimizin kısa bir özetini yapar. Ona göre Cumhuriyet kurulana kadar ortaya konan Batılılaşma çabalarının bir plan ve programı yoktur. Mustafa Kemal, bu eksikliği görmüş ve inkılapları ile ileri hamleler gerçekleştirmeye başlamıştır. Atay, Mustafa

k1839'da Tanzimat fermanı ile birlikte bazı konularda şeri hükümler yetersiz kalmış ve yarı teokratik ve yarı laik yapıda olan mecelle hazırlanmıştır. Mecelle miras, aile taşınır taşınmaz mallardaki mülkiyet işlerinde İslam hukukuna dayandırılmış, kara ve deniz ticareti gibi konulara da Fransız kanunlarını dayandırılmıştır. Mecelle dini esaslara dayandırıldığı için yeni ihtiyaçlara cevap verememekteydi. Bu sebeple batı normları esas alınarak Medeni kanun kabul edilmiştir. (Safran, 2010: 200). 
Kemal'in altı ilkesinden birisi olan inkılapçılığı, yazılarında sık sık konu edinir. Atay'a göre Türkiye'nin iki önemli davası vardır. Bunlar 1)maziyi tasfiye etmek 2)geleceği hazırlamaktır. $\mathrm{Bu}$ düşüncesini 10 Şubat 1937 tarihli yazısında işleyen Atay maziyi tasfiye etme zorunluluğunu açıklamayı görev edinmiş gibidir. Ona göre kurtuluşta ve rejim değişikliğinden sonra mazinin maddî ve manevî müesseselerini yaşatmaya çalışmak beyhude bir çabadır. Çünkü bu çaba, zaferi ve onun eserlerini yıpratabilecek bir çabadır. Zafer, yeni Türkiye'nin, dogmaları temizleyerek çağdaş dünyada söz sahibi olmasını gerektirmektedir. $\mathrm{Bu}$ nedenle de Kemalizm'in esaslarına "hıyanet etmemek" gerekir. Atay'ın Kemalizm'e bağlılık konusunda önemsediği kesim gençlerdir. $O$, gençlerin, Kemalist politikanın terbiyesinden geçmesini ister. Bu düşüncesini Atatürk'ün halkçllık ilkesini tahlil ederken dile getiren Atay'ın halkevlerini sık sık konu edinme nedeni gençlerden beklentileridir. 21 Şubat 1937 tarihli yazısında halkevlerini Kemalizm' in hakiki ocağı olarak gören Atay şunları söyler: "Bütün meslek gençleri, hepsi, onların çatısı altında inkılap politikası terbiyesine, en aşağı meslek bilgileri kadar ehemmiyet vererek, ve gene o çatı altında, kendilerini halk hizmetlerine vakfederek, cumhuriyet vatandaşlığı vazifelerini yapmış olurlar."

Görüldüğü gibi Atay, genç neslin halkevlerinde alacağ terbiyenin genç Cumhuriyet'in önemli gereklerinden biri olduğunu düşünür. Çünkü o, devletin halkı ile var olduğuna ve halk lehine hiçbir fedakârlıktan çekinilmemesi gerektiğine inanır. Atay 9 Şubat 1936 tarihli "Halkçı Devlet" başlıklı yazısında hükûmetin halkın yaşam koşullarını iyileştirmek için aldığı kararları yorumlar. 27 Şubat 1936 tarihli yazısına ise "Halkçı Gençlik" başlığını verir ve yine halkevlerinin ülkedeki önemi ve yetişen genç nesiller için taşıdığ 1 anlam üzerinde durur. Onun halkçılık ilkesi ile halkevleri meselesindeki çıkış noktası, "Halkçı Gençlik" başlıklı yazısında işlediği gibi, halkından kopan ve böylece köksüzleşen aydınların ve yöneticilerin ülkelerine verdiği zarardır. Yazar, Mustafa Kemal'in, partisine "Halk Partisi" ismini vermesini de bu bağlamda değerlendirir. 12 Mayıs 1936 ve 30 Mayıs 1936 tarihli yazılarında Halk Partisi'nin, isminden kaynaklanan bir yaklaşımla yürürlüğe koyduğu kimi kanunları yorumlar. Bunlardan biri olan İş Kanunu'nun yeni devletin en çok ihtiyaç duyduğu toplum çeşidini; "sınıfsız toplum" $u$ yaratmaya yönelik bir çaba olduğunu düşünür. 30 Mayıs 1936 tarihli yazısında İş Kanunu'nun toplumu hangi açılardan rahatlayacağını tahlil eden Atay, toplumdaki ve çalışan kesimdeki adaletsizliklerin iktidar tarafından bu kanun ile bertaraf edildiğini belirtir. İktidar kavramı ile neyi belirttiğini ise Atay 3 Mayıs 1936 tarihli yazısında açar. O, "iktidar" derken, "Kemalizm hükûmetçiliği" kavramına vurgu yapmaktadır. Atay'a göre Mustafa Kemal'in 1920'den beri devlete entegre etmeye çalıştığ hükûmetçiliğin üç ilkesi vardır ve bunlar; “kanun, iş, prensip"tir. Kemalist hükûmet 1920'den beri bütün iç ve dış tahriklere rağmen prensipler belirlemiş, kanunlar çıkarmış ve bütün bunları icraata dökebilmiştir.

Yukarıda bahsi geçen "iç ve dış tahrik" meselesi, Atay'ın Atatürk konulu yazılarında konu edindiği en önemli meselelerden birisidir. Örneğin yazar, Atatürk'ün dikta yönetimi uyguladığına dair duyum ve tezleri köşesinde sık sık eleştirirken asla saldırgan bir üslup takınmaz. Aksine; dikta ne demektir, dikta yönetiminin gerekleri nedir, dikta bir ülkede nelere sebebiyet verir gibi sorular çerçevesinde, Atatürk ilke ve inkılaplarının dikta yönteminden ne kadar uzak bir tarzı olduğunu anlatmaya çalışır. Onun 10 Şubat 1937 tarihli yazısına başlık olarak seçtiği; "Bir usul farkı" ifadesi, Atatürk yönetiminin herhangi bir dikta yönetiminden usulen nasıl farklılaştığını işleyeceğine dair bir işarettir. Nitekim Atay yazısında, Türkiye Cumhuriyeti Devleti'nin, bizzat Anayasa'nın emniyet altına aldığı prensipler ile dikta ile yönetilemeyeceğine dair ispatlar sunar. Yazar, 3 Mayıs 1936 tarihli yazısında ise Atatürk'ün 
dikta yönetimi uyguladığını düşünenlerin, aslında milletin kurtulma ve kalkınma hamlelerini benimsemeyen menfi kesimler olduğunu belirtir. Yazara göre Atatürk'ün "meclissiz" iş yapmaması, daima kanunlara uygun hareket etmeye çalışması onun diktatör olmadığının en küçük delilidir. ${ }^{1}$

Atay'ın bu soğukkanlı ve tarafsız üslûbu, Mustafa Kemal Atatürk'e yönelik komplo girişimini değerlendirirken bir nebze değişir. Ulus gazetesi, 19 İlkteşrin 1935 tarihli sayısında Mustafa Kemal'e Suriye' de bir komplo düzenlenmeye çalışıldığı şeklinde haberler verir. Buna göre Halep'ten Kilis'e geçen ve isimleri de belirlenen dört kişi, Atatürk'e komplo düzenleyecekleri bilgisi alındığı için, yakalanmışlardırm ${ }^{m}$. Falih Rıfkı bu haberi 30 İlkteşrin 1935 tarihinde köşesine taşır. Öncelikle Atay bu vakayı, kendisi gibi tüm Türk halkının tiksinti ile karşıladığını yazar. Çünkü ona göre Atatürk'e kastetmek tüm Türkiye'ye kastetmek, ulus ve yurt düşmanlığ1 yapmak demektir. Atay; "Atatürk, Türkiye demektir" düşüncesini güttüğü için, Atatürk'ün rakibi veya düşmanı olabileceği ihtimalini kabullenememektedir. Yazar, komplonun fiiliyata dökülmeden engellenmesinden çok memnundur. Bu memnuniyeti biraz da Türk halkının liderini ne kadar sevdiğini ve ona gönülden bağlı olduğunu bildiği içindir. $\mathrm{O}$, ne yaparlarsa yapsınlar, nasıl yaparlarsa yapsınlar Türk halkının bu alçakları kendi kanları içinde boğulmaya mahkûm edeceğinden emindir. Yazar, 12 Şubat 1936 tarihli yazısında Türk halkının Ata'sına duyduğu sevgi ve bağlılığı göremeyen bu alçakları, ahmak olmakla da suçlar. Yazara göre bunlar, Türk halkının kendi sınırları içinde mutlu ve barış dolu günleri beklediğini unutup, diş mihrakların etkisiyle hareket ettikleri için ahmaktırlar.

\section{Falih Rıfkı Atay'ın İç Politikaya Yönelik Yazıları}

\section{Bayındırlık ve İmar Faaliyetleri Konulu Yazıları}

İmparatorluktan ulus-devlete uzayan süreçte gözlemci ve araştırmacı kişiliği ile tanık olduğu hemen her siyasi vakaya yorum yapabilecek eleştiri yapabilecek bir yeteneğe sahip olan Falih Rıfkı Atay, yaşam algı ve sistemini Cumhuriyet sonrasında da değiştirmez. Her ne kadar bunda Atatürk'ün yakınında ve CHP faaliyetlerinin odağında bulunması etkiliyse de yazarın aksiyoner kişiliğinin unutulmaması da önemlidir. Toplumsal ve siyasi yaşama duyarsız kalamamanın etkisiyle tetiklenen bu aksiyoner karakter, Atay'ın ülkenin iç meselelerine yönelik yoğun dikkatinin da çıkış noktasıdır. Muhtelif eserlerinde ve gazete yazılarındaki Türkiye toplum ve siyaseti ile ilgili tespitlerinin, bugün dahi dikkate alınabilecek tarzda olmasının nedeni budur. Örneğin genç Cumhuriyet'in ülkeyi yeniden kurma ve yapılandırma konulu çalışmaları Atay'ın özel önem atfederek eğildiği meselelerdir. Ayrıca Atay’ın konuyla ilgili yorumları taşra-merkez çatışmasının hâlâ sıcak bir çatışma olduğu günümüz Türkiye'si adına dahi önemlidir. Öncelikle Atay, ülkenin bayındırlık ve imar meselesini bir kültür meselesi olarak algılamaktadır. 30 Haziran 1935 tarihli yazısında; "Kültür göze görünür bir şeydir: Kültür sokaklarda, yapılarda, giyinişte, hareketlerde, yapı şekillerinde her şeyde görünür" diyen yazar, imar faaliyetlerinin bir toplumun kültür dokusunun parçası olduğunu düşünür. Fakat

\footnotetext{
'Funda Selçuk Şirin de Atay'ın Kemalist felsefenin önemli savunucularından birisi olduğunu ifade eder. Yazar, Atay'ın bu felsefe adına sarf ettiği çabaları iki başlıkta değerlendirir. Bunların ilki Atay'ın Kemalizm'in tanımlanması ve teorileştirilmesi sürecine yaptığı katkıdır. İkincisi ise Kemalizm'in halka anlatılması ve içselleştirilmesi hususunda gösterdiği çabadır (Şirin,2014: 186).

mLazistan mebusu Ziya Hurşit, meşhur Laz İsmail ve Laz Yusuf'u İstanbul'a Gülcemal vapuru ile getirmişlerdir. Bunlar bomba ve tabancalar ile donanmışlardır. Sarı Efe adıyla anılan kişi bu olay ile tam ilgili kişi olarak görülmüș, bu kişilere bomba ve silah İstanbul'da verilmiștir. Hanesinde toplantı yapılan Giritli Şevki kaptan durumun Mustafa Kemal ile ilgili olduğunu anlayınca haber vermiştir (Selek, 2009: 472).
} 
yazara göre Osmanlı'dan geriye, modern manada herhangi bir mimari miras kalmamıştır. Bu düşüncesini 27 İlkteşrin 1935 tarihli yazısında dile getiren Atay, genç Cumhuriyet'in konuyla ilgili atacağı adımları görev telakkisi ile değerlendirir. Ona göre; "Cumhuriyet temelden ve baştan, maddi ve manevi bir inşa vazifesi ile" karşı karşıyadır. Ĕ̆er Türkiye bu vazifeyi hakkıyla ifa ederse ancak o zaman "dağınık, düzensiz ve Asyalı" görünümünü değiştirecek çağın ileri memleketlerinden biri olarak gösterilebilecektir. Yazarın 29 Mart 1936 tarihli yazısında; kültür, bayındırlık ve teknik kavramlarını, ülkenin "yekpareleşmesi" adına şart koşmasının ve ancak bu şekilde "tam fetih" yapabileceğini düşünmesinin nedeni de imar faaliyetlerini çağın bir gereği olarak görmesidir. Falih Rıfkı, bir medeniyetin, bir devletin ancak bıraktı̆̆1 izlerle değerli olduğunu düşünür ve mimari faaliyetleri bu kapsamda değerlendirir (Ulus gazetesi, 4 İlkteşrin 1935, No:5097: 1).

Falih Rıfkı Atay genç Cumhuriyet'in tüm yöneticilerinin bayındırlık ve imar faaliyetlerinden sorumlu olduğunu düşünmekle beraber, asıl itici kuvvetin belediyeler olduğuna inanır. $\mathrm{Bu}$ nedenle de yazılarında sık sık, belediyeciliğin ne olduğu, nasıl olması gerektiği, belediyelerin parasal kaynakları ve mevcut durumları gibi konuları işler. Ona göre hükûmet belediyelere destek vererek memleketin bayındırlık faaliyetlerini hızlandırmıştır. Bu düşüncesini 6 Şubat 1936 tarihli yazısında dile getiren Atay, verilen desteğin hangi kanunlarla ve hangi bankalar aracılığıyla belediyelere ulaştı̆̆ına dair döküm de yapar. 27 İlkteşrin 1935 tarihli yazısında ise söz konusu desteğin karşılık bulduğunu ve Türk belediyecilerinin bütün zorluklara rağmen durmaksızın çalıştığını ifade eder. Atay'ın 17 Aralık 1935 tarihli yazısı ile 27 Mart 1937 tarihli yazısını su meselesine ayırması da belediye faaliyetlerini önemseme ve halka duyurma çabasıyla ilgilidir. Bu yazılarda çeşitli il ve beldelerde halledilen su sorunu, belediyelerin soruna yaklaşımı, harcanan para miktarı gibi konuları işlern.Yazar,11 Haziran 1935 tarihli yazısında da su meselesini işler. Anadolu'nun asırlardan beri susuzluk problemiyle boğuştuğunu, bu problemin, açlık ve göç anlamına geldiğini söyler. Yazara göre bu sorunun halledilmesi Cumhuriyet Hükûmeti'nin öncelikli görevleri arasındadır. Nitekim Ulus, aynı tarihte, "Ankara'nın su davası kotarılmıştır" başlığını kullanır. Haberde Çubuk barajının temel atma töreniyle ilgili detaylar vardır.

Atay, bayındırlık meselesi kapsamında, hükûmetin yol yapımı konusunda attığı adımları da köşesinde işler. Çünkü o, 26 Şubat 1936 tarihli yazısında belirttiği üzere, yolsuzluğun ülkenin önemli bir sorunu olduğunu düşünür. Ona göre bu sorunun çözümü Türkiye'nin endüstriyel ve ekonomik anlamda atılım içinde olduğuna dair işarettir. Fakat o yol yapımı konusunda ülkede gerçekleşen kimi vakaları beğenmemektedir. Örneğin 15 Şubat 1936 ve 26 Şubat 1936 tarihli yazılarında yollarımızın sağlam yapılmadığından şikâyetçidir. Yazar ülkenin demiryolu ağı ile ilgili gelişmelerinden ise memnundur. 25 Mart 1936' da İsmet İnönü'nün yeni demiryolu duraklarının açılışına katılacağını haber verir. 5 Şubat 1936'da ise Trakya'daki demiryolu inşaatını, Avrupa'ya bağlanma vasıtası olarak görür.

Atay'ın ülkenin imar faaliyetleri konusundaki rahatsızlıkları, yol meselesi ile sınırlı değildir. Yazar şehirlerin değişen mimari dokusunda da eksik ve yanlış uygulamalar olduğuna inanmaktadır. Örneğin 3 Haziran 1935 tarihli yazısında, İstanbul ve Ankara başta olmak üzere tüm şehirlerde yapılan yeni binaların plansız ve estetik yoksunu olduğu savını temellendirmeye çalışır. Ona göre şehirleşme bir ihtisas işidir. Bu nedenle kaynakların doğru

\footnotetext{
n Yazarın su meselesine verdiği önem Çankaya bașlıklı eserinde ișlediği kimi gerçeklerle de ilgilidir. Yazar Cumhuriyet'in kuruluş yıllarında devlet yöneticilerinin belli başlı günlük dertleri arasında su sorunun da bulunduğunu, çünkü yüz yıkayacak kadar su bile bulunmadığını yazar. (Atay, 2003: 485)
} 
kullanımı, doğru planlama ve görsel meselelerin uzmanlar eşliğinde çözümlendiği bir şehircilik anlayışı güdülmelidir. Atay'ın ülkedeki anıt yapımı konusunu 25 Mart 1936 tarihli yazısında dile getirirken de çıkış noktası, anıtların estetik boyutuna sahip olması gerektiği tezidir.

\section{Ĕ̆itim Konulu Yazıları}

Falih Rıfkı Atay, Müslüman Doğu milletlerinin dünyadaki gelişmeleri takip edemediği için emperyalizmin kurbanı olduğunu ifade eder. Bu düşüncesini 11 Haziran 1936 tarihli ve "Medeniyetçilik Cephesi" başlıklı yazısında teferruatlandıran yazar, Doğu'da bir tek ideolojinin bu geleneği yıktığına inanır. Elbette ki bahsettiği ideoloji Kemalizm’dir. Ona göre eğer Türkiye "Kemalizm İnkılabı"nı muvaffakiyetle tamamlarsa "Garp medeniyetinin tam teşekküllü" ve ileri bir üyesi haline gelebilecektir. Falih Rıfkı özellikle ülke içi siyasi sosyal durum ve vakaları bu görüşten yola çıkarak değerlendirir. Örneğin eğitim meselesini Garp medeniyetine dahil olabilmek için çözülmesi gereken önemli meselelerden biri olarak görür. Yazar; dil, tarih, spor, musiki gibi farklı fakat en nihayetinde her biri kültür kavramının alt bileşeni olan bu başlıkları da yine eğitim sistemimizin geldiği hal, değişmesi gereken boyutları, eğitimle ilgili yeni hedefler gibi başlıklarda değerlendirir.

Falih Rıfkı'nın eğitim meselesine yaklaşımı, ele aldığı tüm konularda olduğu gibi, önce durum tespiti yapma, ardından çözüm önerileri sunma aşamalarını içerir. Örneğin yazar, Türkiye'nin eğitim konusundaki en önemli gelişmesinin, yükseköğrenimin yaygınlaşması olduğunu düşünür. 8 Haziran 1935 tarihli yazısını bu düşüncesine ayıran Atay'a göre, Türkiye'de çocuklar artık ilkokuldan yükseköğrenime kadar uzun bir çizgiyi takip edebilme özgürlüğüne sahiptir. Fakat yazar gelinen noktayı yeterli görmez ve hükûmetin yükseköğrenim konusunu planlı ve programlı? yürütmesi gerektiğine dair çözümler de sunar. Onun 23 Ocak 1936 tarihli yazısında Tıp Fakülteleri'nin sayı ve nitelik açısından geliştirilmesi gerektiğine dair ifadeleri, bu bağlamda değerlendirilmelidir. Çünkü yazar 12 Ekim 1935 tarihli yazısında işlediği gibi, ülkenin tıp alanında önemli atılımları olduğunu, fakat Anadolu'da hâlâ bulaşıcı kimi hastalıkların kol gezmesinin kabullenilemeyeceğini düşünmektedir. Falih Rıfkı, 24 Haziran 1936 tarihli yazısında ise Siyasal Bilgiler Fakültesi'nin Ankara'ya taşınması hadisesini değerlendirir. Yazar Fakülte' nin bölümlerini, uyguladığı programı, öğrenci sayısını verdikten sonra asıl meseleye geçer. Ona göre siyasal mezunu öğrenciler, ülkenin her köşesine gidecek ve devlet-halk arasındaki mesafenin halli için uğraşacaktır.

Atay'ın yükseköğrenim meselesi ile ilgili olarak hükûmete sunduğu bir başka tavsiye, Avrupa'daki Türk öğrencilerle ilgilidir. 17 Ağustos1935 tarihli yazısında, Avrupa'ya staj ve eğitim için öğrenci gönderme meselesinin ülkeye yük getirdiğini, bu nedenle öğrenci seçimi ve öğrencilerin Avrupa' daki yaşamları ile ilgili sıkı kontroller yapılması gerektiğini ifade eder. Türkiye' deki okullarda hâlâ süren kimi disiplin uygulamalarını çağ dışı görür. Bu düşüncesini 2 Mart 1936 tarihli yazısında işlerken, çıkış noktası, Kadıköy' de bir öğrenci ile hocası arasında cereyan eden tartışmaya dair aldığı duyumdur. Yazar öğretmenlerimizin çocuklara ve gençlere, daha anlayışlı yaklaşması gerektiğini düşünmektedir. Onun 9 Mart 1937 tarihli yazısındaki öğretmenlerimizin birtakım kurslara tabii tutularak insan odaklı bir anlayışa sahip olabilmelerinin sağlanması gerektiğine dair düşüncesi de aynı yaklaşımı örnekler. Atay bu yazısında okuz iki bin köye öğretmen ataması yapılacağına dair haber karşısında duyduğu memnuniyeti de ifade eder. Onun eğitim konusunda memnuniyet duyduğu başka alanlar davardır. Örneğin 29 Nisan 1935 tarihli yazısında Türkiye'nin kadın-erkek eşitliği konusunda önemli bir seviye yakaladığını ifade eder. Bu seviye Türk kadınının orduda görev 
alabilmesinin yolunu açması açısından da önemlidir. Ayrıca bir durum Kemalizm'in güttüğü davaların haklılığını da örneklemektedir.

Kemalizm, kendisine muasır medeniyet seviyesini hedef bellerken elbette ki çıkış noktası yurt insanıdır. Öncelikle yurt insanı medeniyet değişikliği yaşamak, yüzünü Batı'ya dönmek zorunluluğunu samimi bir şekilde hissetmelidir. Atay Türk halkının konuyla ilgili samimi duyguları olduğuna inandığ1 için, eğitim konusundaki yazılarında gözlemlediği olumlu gelişmeleri memnuniyet hissini öne çıkardığ tarihli yazısına alfabe değişikliğinin zaruri bir ihtiyaç olduğunu belirttiği ifadelerle başlar. Ardından bu değişiklik sayesinde ülkede gazete kitap okuma oranının arttığı gerçeğini, sayılar vererek ispata çalışır. Atay 8 Şubat 1936 tarihli yazısında da kitap dergi neşriyatının arttığını ve bunun okuma oranının yükseldiğine dair bir işaret olduğu fikrini işler. Yazar, yine bu yazısında da kadın ve erkek okuma oranları ile ilgili son istatistikleri paylaşır. Atay'ın tüm memnuniyetine rağmen okuma alışkanlığımız konusunda bir şikayeti de vardır. 8 Ocak 1936 tarihinde dile getirdiği bu şikâyet, kendi tarihimize yabancılığımızı konu alır. Ona göre Türk halkı kendi tarihini, yabancı bilim adamlarının eserleriyle öğrenmeye çalışmaktadır. Hâlbuki son zamanlarda kimi Osmanlı devlet adamlarının hatıraları yayınlanmıştır. Ülkemizle ilgili gerçeklerin bu hatıralardan takip edilmesini salık veren Atay, Ulus'un bunu bir görev olarak telakki ettiğini ve bahsedilen konuyla ilgili kimi eserleri tefrika etmeye başlayacağını da belirtir.

Çalışmanın giriş kısmında belirtildiği gibi Ulus gazetesi; bizzat Atatürk'ün direktif ve katkıları ile başlayan dilde sadeleşme çabalarını sütunlarında sıkça işlemiştir. Falih Rıfkı, gazetenin bu politikasına paralel biçimde, hem başyazılarında hem kimi zaman gazetenin farklı sayfalarında yer bulan fıkra ve denemelerinde Türkçe'nin özünü bulması gerektiğine dair fikirler paylaşır okuruyla. Ona göre yeni Türkiye'nin gerçekten de bir dil sorunu vardır ve bu sorun, eğitim politikalarının önemli bir parçasıdır. Çünkü Türkiye' de hâlâ Türkçe bilmeyen ve konuşamayan insanlar söz konusudur. 14 Mart 1937 tarihli yazısını bu konuya ayıran yazar, eğitim ve kültür politikalarımızın öncelikle halkın Türkçe konuşmasını sağlayacak kurum ve okullar üzerine inşa edilmesi gerektiğini düşünür. Atay bu yolda eğitim ve kültür bakanlarına birtakım çözüm yöntemleri de sunar.30 Nisan 1935 tarihli yazısında ise Türkçe'nin sadeleştirilmesine dair belirlediği çözüm önerilerini 3 madde halinde tahlil eder. Özde, konuşma dili ile yazı dili arasındaki farkın giderilmesine yönelik bu maddeler 1)Yeni kelimelerimizi Oğuz sesine göre ölçmek, 2)50 yıllık dil evrimimizin bizi nereye doğru götürdügünü görmek, 3)Batı kültür dairesinde olduğumuzu unutmamak, şeklinde sıralanmıştır. Atay bu yazısında konuşma dilinde var olan fakat Anadolu halkı tarafından kullanılmayan kelimeleri de örnekler.

Daha önce belirtildiği gibi, Atay'ın yazılarında sık sık işlediği “Garp medeniyeti dairesinde, ileri bir ülke olduğumuz" şeklindeki tezi; spor, musiki, turizm gibi alanlara değinirken de çıkış noktasıdır. Örneğin yazar 23 Aralık 1935 tarihli yazısında hâlâ Şark musikisinin etkisi altında olduğumuzu, musiki konusunda Garp medeniyetini yakalayamadığımızı ifade eder. Atay bu konuda da en ileri görüşlü kişinin Mustafa Kemal olduğunu, konuyla ilgili en ciddi teşebbüsleri bizzat onun yürüttüğünü düşünür. Konservatuar ve orkestra çalışmalarını ise Atay, bu teşebbüslerin örneği olarak görür. Ona göre ülkemizdeki mekteplerde ve Avrupa'ya giden öğrenciler arasında da musikiye yönelik dikkat yaratılmalıdır. Atay 14 Ağustos 1936 tarihli yazısında ise gençlerimizin kimi spor dallarına yönlendirilmesi konusunda teşvik edici davranılmasını ister. Bu yazısında Atay, Berlin olimpiyatlarında güreş dalında alınan 
madalyalardan duyduğu memnuniyeti de işler. Yazarın 9 Ocak 1936 tarihli yazısı ise ülkemizde turizmin nasıl canlandırılabileceği, turistlerin Türkiye'ye nasıl daha kolay gelmesinin sağlanabileceği konusunu içerir. Yazı, ülkemizde turizm konusunda bir bilinçlenme süreci yaşanması gerektiğine dair tezi nedeniyle, Atay'ın eğitim konulu yazılarına dahil edilebilecek cinstedir.

\section{Sanayi ve Tarm Konulu Yazılar}

Falih Rıfkı Atay'ın, ülkenin yeniden yapılanma sürecini takip ederken ilgilendiği bir diğer alan, tarım ve tarımsal üretime bağlı sanayi alanındaki gelişmelerdir. 21 Haziran 1936 tarihli yazısında, ülkemizde pirinç üretiminin arttı̆̆ını, çeltik tarlalarının oranını verecek kadar teferruatlandıran Falih Rıfkı, devletin pirinç politikalarını da beğenmektedir. Aynı şekilde 16 Aralık 1935 tarihli yazısında da pamuk üretimini konu alan yazar, Türk köylüsünün üzerine düşeni layıkıyla yerine getirdiğini düşünür. Yine burada da genç Cumhuriyet hükûmetinin pamuk üretimimiz konusundaki rehaveti; fabrika kurarak, tezgâh açarak ve uzman kişiler yetiştirerek kolayca hallettiğini düşünür. Onun tarımsal faaliyetler konusunda eleştirdiği kesim, esnaf kesimdir. Nitekim 2 İlkteşrin 1935 tarihli yazısında incir ihracatını konu edinirken yaptığı uyarılar bugün dahi dikkat edilmesi gereken hususlardandır. Öncelikle yazar, dünya ülkelerinin dış ticaret meselesini disiplin ve güven üzerine inşa ettiğini düşünmektedir. Ülkemizde ise dış ticaret şahsî kazançlar ön planda tutularak yapılmaktadır. Dolayısıyla ülkemizin ihracat konusunda sıkı kanun ve uygulamalara ihtiyacı olması bir yana, kişilerin ulusal çıkarları öncelemesi şarttır. Falih Rıfkı'nın tarımsal üretimi; tarla, işçi, tezgâh sayı ve oranları vererek işlemesi söz konusu "ulusal çıkar" kavramıyla ilgilidir. Atay bütün bu üretim faaliyetlerinin millî endüstrinin kurulması anlamına geldiğini düşünür. 16 Aralık 1935'te işlediği bu düşüncesine göre, yerli ürün, yerli makine, yerli teknik demek, Kemalizm'in nihaî hedefi olan, millî zafer demektir. Yazar ülkedeki fabrika sayılarının ve niteliklerinin yükselmesinden dolayı duyduğu sevinci işlerken de bu gelişmeleri millî zaferin aşamaları olarak görür. 3 Aralık 1935 tarihli yazısında önce gazetelerin yeni fabrikalarla ilgili verdiği haberleri değerlendirir. Ardından ülkemizde ithal edilen mal kullanma geleneğini, ipekli dokumaları örnek vererek eleştirir. Dolayısıyla Atay, yeni fabrikaların yerli üretim konusunda vereceği desteği önemseyerek konuşur. Ona göre kendi mal ve maddelerimizin işleneceği bu fabrikalar, belki de dışarıya bağımlılı̆̆ yok edecektir. Nitekim yazar, 27 Kasım 1935 tarihli yazısında; kağıt, şişe-cam, ipek dokuma, halı fabrikalarının açılması ile ilgili haberi değerlendirirken buralarda üretilen malın Türkiye' nin zengin ve refah içinde yaşayan bir ülke olmasını sağlayacağına inanmaktadır. Bu, Türkiye'nin kapitalizme boyun eğmediği anlamına geldiği için, Falih Rıfkı nazarında umut verici ve önemli bir durumdur.

\section{Falih Rıfkı'nın Havacılık Faaliyetleri ile İlgili Yazıları}

Ülkenin yeniden yapılanma sürecindeki her hadiseyi köşesinde işlemeyi unutmayan Falih Rıfkı, Türk Hava Kurumu'nu ve faaliyetlerini de değerlendirir. Bu değerlendirmede iki ana mevzu söz konusudur. Bunlardan ilki, bir ülkenin hava sahasına dair güvenliğinin sağlanması hususunun önemidir. Yazara göre dünyanın içinde olduğu değişim, harp tekniklerini de etkilemiştir. Savaşlarda artık hava saldırıları belirleyici unsur olmuştur. Bu düşüncesini 7 Ekim 1935 tarihli yazısında işleyen Atay, Türkiye'nin konuya dünya ülkelerinden daha çok özen göstermesi gerektiğine inanır. Çünkü o, Türkiye rüyası görenlerin hâlâ tetikte beklediğini 
ve ülkemizin en küçük zaafını değerlendirmeye çalıştıklarını öngörmektedir. Yazar aynı düşüncesini 29 Mayıs 1935'teki yazısında da işler. Fakat bu defa hava saldırılarının daha geniş oranda yapılabileceği, örneğin havadan ülkemize zehirli gaz şişelerinin dahi atılabileceğini ifade eder. Bu nedenle Türkiye' nin hava güvenliğini sağlaması önemlidir. Atay aynı mevzuyu 11 ve 16 Mayıs 1936 tarihli yazılarında da işler. 11 Mayıs'taki yazısında Rusya ve çeşitli Avrupa ülkelerinin havacılık faaliyetlerine verdiği önemi, ayırdığı bütçeyi örnekler. 16 Mayıs'ta ise havacılık faaliyetleri açısından uçağın önemini öne çıkarır (Ulus gazetesi, 16 Mayıs 1936, No: 5315: 1). Ona göre uçak, herhangi bir savaş anında fetih vasıtası olması bir yana, ülkeleri ve cemiyetleri birbirine yaklaştırması bakımından da önemli bir teknik vasıtadır. Yazarın 25 Mayıs 1936 tarihli yazısı da bu bağlamda değerlendirilebilir. Atay bu yazısının girişinde Ulus'ta daha önceki günlerde yayınlanmış bir fotoğrafı konu alır. Bu fotoğrafta Başbakan İnönü, ailesi ve Bayındırlık Bakanı ile Türk Hava Yolları'na ait bir uçaktadır. Yazar bu fotoğraftan yola çıkarak ülkemizde sivil havacılık faaliyetlerinin de yaygınlaştırılması gerektiğine dair tezini işler.

Atay'ın konuyla ilgili yoğunlaştı̆̆ı ikinci nokta, halkın Türk Hava Kurumu'na verdiği destektir. Hükûmet, halkın Türk Havacılık faaliyetlerini bütçesi oranında desteklemesi için çağrı yapar. Atay, bu çağrıyı 28 Mayıs 1935'te köşesine taşırken Başbakan'ın Türk Hava Kurumu'nun altıncı kurultayında yaptığı konuşmayı değerlendirir. İktibaslarla Başbakan'ın hava sahası güvenliği için dikkat çektiği noktaları sıralar. Son olarak da kendisi, halkı, Türk Hava Kurumu'na destek olmaya çağırır. Yazar 19 Şubat 1936 tarihli yazısında ise Türk Hava Kurumu'nun on ikinci kuruluş yıldönümünü konu alır. Atatürk'ün ve İnönü'nün “hava davamızı" halka anlatabilmek için seferberlik ilan ederken kullandıkları ifadeleri alıntılayan yazar, gelişmelerden memnundur. Bu memnuniyetini sahip olduğumuz uçak sayısı, Türk Kuşu'nun yetiştirdiği pilot, paraşütçü sayısı gibi bilgilerle de açığa vurmaya çalışan Atay, çıtayı daha da yükseltmek gerektiğini belirtmeden geçmez (Ulus gazetesi, 19 Şubat 1936, No:5331: 5).

Onun konuyla ilgili memnuniyetini ifade ettiği bir diğer yazısı da 16 Mart 1937 tarihlidir. Bu tarihten bir gün önce İstanbul Yeşilköy'de Türk kuşu Bayramı kutlanmıştır. Atay bu bayrama halkın gösterdiği ilgiden dolayı çok gururludur. Yazar bu ilgide Türk kuşu'nun önemli etken olduğunu, ama bunun havacılık faaliyetlerinin bir spor dalı olarak algılanması ile ilişkisinin olmadığını belirtir. Ona göre Türk halkı, uçağın, hava faaliyetlerinin ve hava sahasının güvenliği konusunun önemini kavramıştır.

\section{Sonuç}

Falih Rıfkı Atay, İmparatorluk'tan Ulus-Devlet'e geçiş sürecine tanıklık etmiş neslin önemli temsilcilerindendir. $\mathrm{Bu}$, onun her iki dönemde de devlet adamlarına dolayısıyla devletin işleyişine ve basın dünyasına yakın olmasıyla ilgili bir durumdur. Falih Rıfkı içinde ve yakınında olduğu bu alanları iyi değerlendirir. Tanık olduğu sosyal ve siyasi vak'aları sebep ve sonuçları ile tahlil ederek özümserken değerlendirmelerini kamunun yararına sunmak için de uğraşır. Ulus gazetesi, onun konuyla ilgili çabaları için vasıta kıldığı en önemli yayın organlarından birisidir. Nitekim Atay çalışmaya esas teşkil eden 1935-1937 yılları arasında Ulus gazetesinin başyazarı olarak hazırladığı köşesinde, daima kamu yararını ön planda tutar. Örneğin yazar dış dünyada olup bitenler ile Türkiye ve dış dünya arasında yaşananları resmederken halkın bilgi edinme ihtiyacından öte, meselelere daha geniş perspektiften bakabilmesi için uğraş verir. Bu nedenle dış dünya ile ilgili tahlillerini, tarihsel ve siyasî 
konjonktür hakkındaki açıklamaları ile bağdaştırır. Bu noktada Atay'ın dış dünya ilgisinde iki önemli tezi söz konusudur. Bunlar; özellikle Avrupa ülkelerinin emperyalist politikalar geliştirdiği; buna karşı ise Türkiye'nin daima barışçıl bir dış siyaset güttüğü yolundaki tezledir. Yazar, dönemin önemli siyasi gelişmelerinden olan Habeşistan meselesine, Avrupa'nın emperyalist bakışını değerlendirerek eğilir. Onun; Boğazlar ve Hatay meselesinde ise çıkış noktası Türkiye'nin bu meselelerdeki haklılığı olup yazar önce bölgemizdeki huzur ve emniyet için uğraştığımızı açıklamaya çalışır.

Bilindiği gibi, Falih Rıfkı Atay, Kemal Atatürk'ün en yakınındaki isimlerden birisidir. Millî Mücadele sürecinde başlayan ve Atatürk'ün ölümüne kadar devam eden bu süreç, çift yönlüdür. Mustafa Kemal Atatürk, Falih Rıfkı Atay'a değer verir; çünkü Falih Rıfkı, onun inşa etmek istediği yeni Türkiye idealine gönülden bağlı isimlerdendir. Bu durum Atay'ın Kemalist ideolojiye bağlanmasına ve bu ideolojinin unsurlarını ve hedefini halka benimsetmek için uğraşmasına neden olur. Yazar Ulus gazetesindeki yazılarında sık sık, Kemalist ideolojinin halkçılık, inkılapçılık, devletçilik gibi bileşenlerini tahlil eder. Elbette ki bunların tümü, Atatürk'e karşı duyulan sevgi ile harmanlanmış yazılardır.

Atay'ın ülkenin iç meseleleri ile ilgili yazıları da aynı ideoloji çerçevesinde gelişir. Atay ele aldığ 1 tüm meseleler için Kemalist İdeoloji'nin çözüm yöntemlerini ve hedeflerini çıkış noktası yapar. Örneğin yazar ülkenin değişmekte olduğunun en önemli kanıtı olarak bayındırlık ve iskân faaliyetlerini görürken, bu faaliyetleri Kemalizm'in "çă̆gdaş medeniyet" anlayışının bir gerçeği olarak algılar. Buna göre Türkiye, Garp medeniyetinin ileri bir üyesi olabilmek için Şark ülkeleri gibi değil, Garp ülkeleri gibi kültüre sahip olmalıdır.

Yazar; eğitim, tarım, sanayi gibi yenilenmekte ve gelişmekte olan alanların da ülkemizi Garp kültürünün dairesi içine dahil etmesi gerektiği fikrindedir. Bu nedenle de yazılarında adı geçen alanlarda neyin nasıl yapılması gerektiği konusunda birçok çözüm önerisi söz konusudur. Ele aldığı tüm meselelerdeki tespitlerinin, hem siyasi ve tarihi konjonktür, hem de çözüm önerileri ile birlikte sunulması ise Falih Rıfkı'nın başyazılarını değerli kılan en önemli unsurdur.

\section{Kaynakça}

Abadan, N. (1961).“Cumhuriyet ve Ulus Gazeteleri Hakkında Muhteva Tahlili (Content Analysis)", Ankara Üniversitesi Siyasal Bilgiler Fakültesi Dergisi, C. 16, S. 2, s. 93-118

Althusser, L. (1989). Devletin İdeolojik Aygıtları, İletişim Yayınları, İstanbul.

Aktaş, Ş. (2003). “Falih Rıfkı Atay'ın Hayatı ve Sanatı Üzerine Bir Yazı”. Falih Rıfkı Atay. Seçmeler, (Hzl. Mustafa Yücel), Ankara: Berikan Yayınevi.

Armaoğlu, F. (1986). 20. Yüzyıl Siyasi Tarihi (1914-1995), Alkım Yayınları, İstanbul.

Atay, Falih Rıfkı (1968), Çankaya, İstanbul: Pozitif Yayınları.

Bakacak, A. (2002). İkinci Dünya Savaşı Dönemi'nde Ulus Gazetesi'nin İç ve Dış Politika Değerlendirmesi, Yayımlanmamış Yüksek Lisans Tezi, Ankara, Ankara Üniversitesi Türk İnkılap Tarihi Enstitüsü.

Coşar, Ömer S. (1964). Millî Mücadele Basını, İstanbul: Gazeteciler Cemiyeti Yayını 
Çolaker, V. (2008). Türk Siyasal Yaşamında Falih Rıfkı Atay, Yayımlanmamış Yüksek Lisans Tezi, Anadolu Üniversitesi, Sosyal Bilimler Enstitüsü, Eskişehir.

Dayı, E. (2002). “Hatay Devleti ve Hatay'ın Anavatan'a Katılması”, Atatürk Üniversitesi Türkiyat Araştırmaları Enstitüsü Dergisi, Sayı:19, Erzurum, 2002, ss.331-340.

Er, T. (2003). Türkiye'de Basın Yayın ve Tanıtma, Ankara: Ümit Yayıncılık.

Gevgilili, A. (1983). “Türkiye Basını", Cumhuriyet Dönemi Türkiye Ansiklopedisi, C. I, İstanbul: İletişim Yayınları,

Girgin, S. (2012). Falih Rıfkı Atay'ın Gezi yazılarında Avrupa, (Basılmamış Yüksek Lisans Tezi), Doğu Akdeniz Üniversitesi, Kıbrıs- Gazi Mağusa.

Tamer, A. (2004). İrade-i Milliye, 1. Baskı, İstanbul: Tüstav Yayınları.

İnuğur, N. (1992). Türk Basın Tarihi, I. Baskı, İstanbul: Gazeteciler Cemiyeti Yayınları

Koloğlu, O. (1993). Türk Basını, 1. Baskı, Ankara: Kültür Bakanlığı Yayınları.

Kıran, A. (2008). "Milletler Cemiyeti Ve Önlenemeyen Savaş”, Girne American University Journal Of Social and Applied, Sciences 3(6), ss.19-36).

Mutluer, R. (1976). 50 Yılın Türk Edebiyatı, İstanbul: Türkiye İş Bankası Kültür Yayınları.

Şirin, F. S. (2014), Imparatorluk'tan Cumhuriyet'e Bir Aydın: Falih Rıfkı Atay, Birinci Baskı, İstanbul: Tarihçi Kitabevi.

Safran M. ve Diğerleri. (2010). Atatürk ilkeleri ve İnkılap Tarihi, Ankara: Okutman Yayıncılık.

Selek, S. (2009). İsmet İnönü Hatıralar, İstanbul: Bilgi Yayınevi.

Sander, O. (2011). Siyasi Tarih (1918-1994), Ankara: İmge Yayınları.

Tanzimat'tan Bugüne Edebiyatçılar Ansiklopedisi, Atay, Falih Rıfkı, Cilt I. Yapı Kredi Yayınları, İstanbul 2010, Üçüncü Baskı, s. 140-141.

Topuz, H. (2011). Türk Basın Tarihi, Remzi Kitabevi, İstanbul, Üçüncü Baskı

Uçarol, R. (2010). Siyasi Tarih, Der Yayınları, İstanbul.

Yalçın, D. Diğerleri. (2002). Türk Cumhuriyet Tarihi I, Atatürk Araştırma Merkezi, Ankara.

Yel, S. (2009). Değişen Dünya Şartlarında Karadeniz ve Boğazlar Meselesi, Ankara: Atatürk Araştırma Merkezi.

\section{Süreli Yayınlar}

Ulus Gazetesi 1935, 1936, 1937 